\title{
Research Article \\ Effect of Nitrite Inhibitor on the Macrocell Corrosion Behavior of Reinforcing Steel
}

\author{
Zhonglu Cao, Makoto Hibino, and Hiroki Goda \\ Concrete Laboratory, Department of Civil Engineering, Kyushu Institute of Technology, Kitakyushu-shi 804-8550, Japan \\ Correspondence should be addressed to Zhonglu Cao; caozhonglu@126.com
}

Received 19 November 2014; Accepted 28 February 2015

Academic Editor: Katarina Marušić

Copyright (C) 2015 Zhonglu Cao et al. This is an open access article distributed under the Creative Commons Attribution License, which permits unrestricted use, distribution, and reproduction in any medium, provided the original work is properly cited.

\begin{abstract}
The effect of nitrite ions on the macrocell corrosion behavior of reinforcing steel embedded in cement mortar was investigated by comparing and analyzing the macrocell corrosion current, macrocell polarization ratios, and slopes of anodic and cathodic steels. Based on the experimental results, the relationship between macrocell potential difference and macrocell current density was analyzed, and the mechanism of macrocell corrosion affected by nitrite ions was proposed. The results indicated that nitrite ions had significant impact on the macrocell polarization ratios of cathode and anode. The presence of nitrite could reduce the macrocell current by decreasing the macrocell potential difference and increasing the macrocell polarization resistance of the anode.
\end{abstract}

\section{Introduction}

In reinforced concrete structures, the employment of corrosion inhibitor to prevent the steel corrosion induced by the aggressive ions has been a common practice for many years. The advantage of using inhibitor to provide corrosion protection is due to its easy handling and economical advantage; besides the inhibitor is well distributed throughout the concrete, which means that it protects all the steels. A good inhibitor must have two important features [1], namely, to reduce the corrosion of steel to the maximum extent and not affect the strength properties of the concrete. Numerous corrosion inhibitors have been suggested, but the detrimental effects of many of them in concrete limit their commercial use. Among the different chemical substances tested as inhibitors of steel corrosion in concrete, sodium and calcium nitrite are those which have shown the best physical-chemical compatibility with concrete. However, sodium nitrite suffers two disadvantages; one is the reduction of concrete strength and the other is the risk of the alkali-aggregate reaction which can be made worse by the addition of sodium salt. The use of calcium nitrite eliminated the disadvantages of sodium nitrite, but in laboratory study, sodium nitrite was often used to investigate the inhibiting effect of nitrite on the corrosion of reinforcing steel.
The role of free nitrite is its oxidizing action upon $\mathrm{Fe}^{2+}$ which promotes the formation of maghemite $\gamma \mathrm{Fe}_{2} \mathrm{O}_{3}$ and forms an insoluble stable complex passive layer. The passive layer might actually possess a stratified structure, shifting from a $\mathrm{Fe}(\mathrm{II})$-rich, amorphous inner layer to a $\mathrm{Fe}(\mathrm{III})$ rich, more crystalline outer layer [2]. The properties and compositions of the passive film are not improved by the presence of nitrite ions $[3,4]$. The main effect of nitrite is to accelerate the oxidation green rusts into $\mathrm{FeOOH}$ phases [5] and cause the formation of a less porous and more compact oxide. While nitrite is absent, the surface of oxide layer possesses more structural defects and higher surface roughness [6].

As one of the methods to prevent the corrosion of reinforcing steel, nitrite-based corrosion inhibitors, irrespective of being directly added into concrete during the mixing process or penetrating into concrete by the surface-applied remedial treatment, have been widely investigated in chloride contaminated concrete, carbonated concrete, and cracked concrete, and their inhibiting efficiencies also have been checked in simulated concrete pore environment, such as in highly alkaline environment, carbonated environment, and neutral and acid environment. In chloride contaminated concrete, many works have shown that nitrite ions are very effective in shifting the corrosion potential towards 
electropositive direction [7], reducing the corrosion rate of steel, delaying the initiation time of corrosion, and raising the chloride threshold level [8]. The inhibiting efficiency of nitrite ions in concrete strongly depends on the cement contents [8], cement types [7,9], and the air void contents of the steel-concrete interface [8]. In carbonated concrete, high $\mathrm{CO}_{3}{ }^{2-}$ concentration favors the development of a passive film that becomes more compact when nitrite ions are added [10]. According to the study of Alonso and Andrade [11], nitrite ions have a beneficial effect in reducing the corrosion rate of moderately precorroding steel in carbonated concrete without chloride. However, in the case of carbonated concrete with even low levels of chloride, it was found that nitrite was ineffective and was not enough to reduce the corrosion rate and the steel corroded at a rate similar to that when no nitrite was present in the concrete. Similar results could be confirmed by the study of Ngala et al. [12]. In cracked concrete, Montes et al. [13] and Kondratova et al. [14] found that nitrite alone, in general, had no effect in decreasing corrosion, and the crack condition of the specimens strongly affected the corrosion process. In simulated concrete pore solution, nitrite was found to be effective in inhibiting pit initiation [15] and pit propagation [16]. Chloride threshold level was not only increased with the increasing of nitrite concentration but also affected by $\mathrm{pH}$ [17]. The inhibiting efficiency of nitrite decreased when the $\mathrm{pH}$ was reduced [18]. In neutral and acid solutions simulating the electrolytic environments of micropores of concrete in the propagation period, any addition of nitrite cannot effectively reduce the corrosion level [19]. Highly alkaline environment plays an important role in assisting nitrite to inhibit corrosion [17]. However, the study done by Mammoliti et al. [20] in synthetic alkaline pore solution indicated that nitrite ions were unsuccessful in increasing the chloride threshold level of steel exposed to chloride and had a minimal effect on corrosion rate once corrosion was initiated.

As mentioned above, although a lot of work has been done to investigate the effect of nitrite ions on the corrosion performance of reinforcing steel, the knowledge level is continuously extending. Up to now, no attention is given to the inhibiting effect of nitrite ions on the macrocell corrosion behavior of reinforcing steel.

Additionally, in these studies mentioned above, the anodic parts and cathodic parts of steel are microscopic in size and located adjacent to each other. Actually, in the field reinforced concrete structures, anodic parts are connected with cathodic parts in a far or near distance, which may be prone to the formation of macrocell corrosion. The formation of macrocell circuit can lead to the transfer of electrons from anode to cathode and the formation of macrocell current flowing from cathode to anode and therefore result in the shift of cathodic potential toward the direction of negative value, which is called macrocell polarization of cathode, and the shift of anodic potential towards the direction of positive value, which is called macrocell polarization of anode. So when nitrite ions are applied to the chloride-contaminated concrete structures, whether nitrite is effective in improving the macrocell current or has an effect on the macrocell polarization of cathode and anode, is very worthy of consideration, and attracts the interests of the author and up to now, no literature gives the answer. What is more, in these studies, the mechanism of nitrite ions to inhibit the corrosion of steel was mainly discussed by the use of microcell corrosion theory and was not explained from the viewpoint of macrocell corrosion theory. So the mechanism of macrocell corrosion affected by nitrite ions was not clear, and as far as known by the authors, no literature clarifies this.

For all these reasons, the main objective of this study was to investigate and clarify the influence of nitrite ions on the macrocell corrosion behavior of reinforcing steel. Firstly, the relationships between macrocell current density and macrocell potential difference of steels in mortars with various nitrite concentrations will be analyzed. Subsequently, the influence of nitrite on the macrocell polarization ratios and macrocell polarization slopes of cathode and anode will be investigated, and then the mechanism of macrocell corrosion affected by nitrite will be proposed.

\section{Experimental}

2.1. Materials. Plain round mild steel bars $19 \mathrm{~mm}$ in diameter and $180 \mathrm{~mm}$ in length were used in the experiment. The chemical composition of the steel was (wt\%): $0.146 \mathrm{C} \%$, $0.223 \mathrm{Si} \%, 0.521 \mathrm{Mn} \%, 0.019 \mathrm{P} \%, 0.010 \mathrm{~S} \%$, and balanced Fe. At one end of the steel bar, a lead wire was fixed to the steel by screw and the connection area was sealed by polystyrene (PS) resin. In order to prevent any atmospheric corrosion and enhance the reliability and accuracy of measurement, the two bare ends with $40 \mathrm{~mm}$ in length of the steel were firstly coated with polystyrene (PS) resin and then were coated with epoxy resin. The exposed area of the steel was $59.7 \mathrm{~cm}^{2}$. The surface of the exposed area was polished by sandpaper number 180 and cleaned with acetone just prior to being placed in the mold so as to ensure the accuracy of the experimental results $[21,22]$.

The corrosion behaviors of steel bars were investigated in cement mortar blocks with a dimension of $80 \times 80 \times$ $160 \mathrm{~mm}$ as shown in Figure 1. Each mortar block contained a centrally located steel bar and four uniformly distributed small holes which were $6 \mathrm{~mm}$ in diameter and $8 \mathrm{~mm}$ in distance away from the central steel. For each small hole, polypropylene pipe with $6 \mathrm{~mm}$ in outer diameter and $5.8 \mathrm{~mm}$ in inner diameter was inserted in the hole and bended upward into 90-degree angle, so that nitrite solution could be easily filled into the holes. The injection of nitrite ions into the four small holes can simulate the process that nitrite ions penetrate into cement mortar and prevent or inhibit the corrosion of steel by surface-applied remedial treatment using nitrite-rich materials. The change of half-cell potential and macrocell corrosion current that resulted from the addition of nitrite solutions can give an intuitive understanding of corrosion mechanism as well as experimental verification on the influence of half-cell potential difference on the macrocell corrosion and polarization.

For each cement mortar block, the mix proportion of water/cement/sand was $0.7: 1: 5$. Ordinary Portland cement 


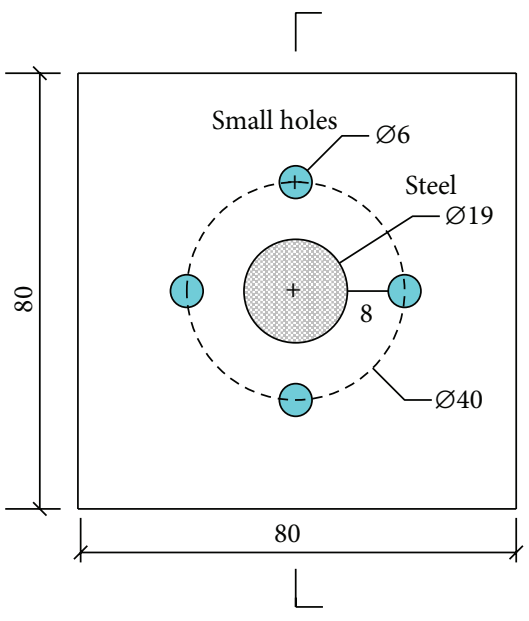

(a)

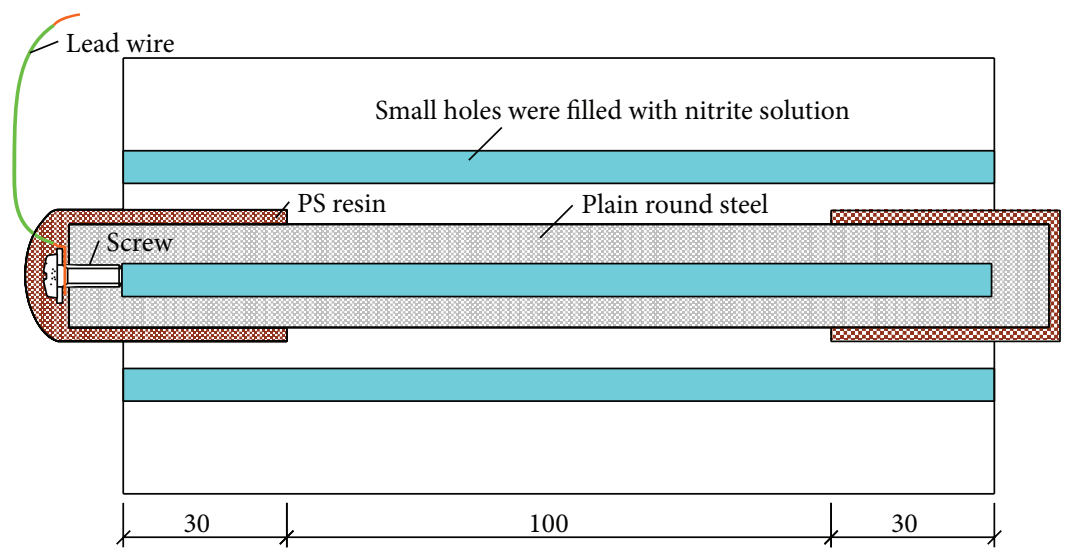

(b)
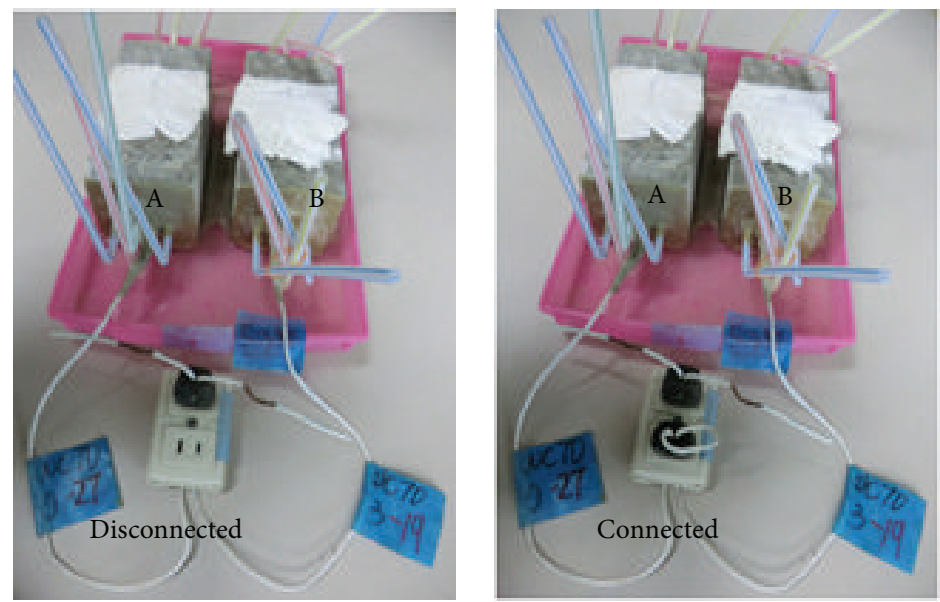

(c)

FIGURE 1: Specimens used in this study (unit: $\mathrm{mm}$ ). (a) Cross section, (b) longitudinal section, and (c) actual specimens.

that was utilized had a density of $3.15 \mathrm{~g} / \mathrm{cm}^{3}$ and met the specification requirements of JIS R5210. Sea sand passed through the JIS A 1102 sieve number 4 ( $4.75 \mathrm{~mm}$ opening) and washed by tap water was selected as the fine aggregate. Its density and water absorption were $2.58 \mathrm{~g} / \mathrm{cm}^{3}$ and $1.53 \%$, respectively. The relatively high value of water/cement ratio and sand/cement ratio chosen in this experiment was mainly for the need to increase the permeability of cement mortar and consequently reduce the time that nitrite ions diffuse to the surface of steel. For some specimens, chloride ions (3 wt $\%$ of cement) were added into the cement mortar at the time of casting by means of $\mathrm{NaCl}$ dissolved in the mix water. When chloride ions were directly added into the cement mortar, there was no time for the steel to be passivated. Additionally, adding chloride ions into the cement mortar had an influence on the properties of mortar. The reasons for doing this in our study were, firstly, to accelerate the corrosion of steel and secondly to produce the same chloride content on the steelmortar interface and so as to easily compare the influence of nitrite concentration on the macrocell corrosion behavior of steels. All the specimens were allowed to set and harden in the mold for 1 day before being demolded and then continuously cured for the next two weeks under water in the $20^{\circ} \mathrm{C}$ constant temperature room. After that, they were allowed to dry under a laboratory environment for another two weeks, prior to the beginning of experiment measurements.

2.2. Methods. The experimental design was shown in Table 1. Each case in Table 1 consisted of two specimens that were defined as A-side and B-side. Polished steels were used in both A-side and B-side in order to give the steels the same initial surface condition and reduce the impact of various steel surface conditions on the macrocell behaviors of the cathode and anode [21]. The specimens in A-side and Bside had the same water-cement ratio but contained different chloride contents. The difference in chloride contents formed a greater potential difference between the steels in A-side and $\mathrm{B}$-side and allowed for clear observation of the macrocell polarization behaviors of the cathode and anode. The chloride content in the specimens of A-side was $0 \mathrm{wt} \%$ of cement while the chloride content in the specimens of B-side was $3 \mathrm{wt} \%$ of 
TABLE 1: Case design for the effect of nitrite ions.

\begin{tabular}{|c|c|c|c|c|c|c|c|c|c|c|c|c|c|c|c|c|c|c|c|c|c|c|c|c|}
\hline \multirow{2}{*}{ Case } & \multirow{2}{*}{ A-side } & \multirow{2}{*}{ B-side } & \multicolumn{22}{|c|}{ Cycles } \\
\hline & & & 1 & 2 & 3 & 4 & 5 & 6 & 7 & 8 & 9 & 10 & 11 & 12 & 13 & 14 & 15 & 16 & 17 & 18 & 19 & 20 & 21 & 22 \\
\hline $\mathrm{N} 1$ & P70-0-27 & P70-3-19 & $\mathrm{D}$ & $\mathrm{D}$ & $\mathrm{D}$ & $\mathrm{D}$ & $\mathrm{D}$ & $\mathrm{D}$ & $\mathrm{R}$ & $\mathrm{R}$ & $\mathrm{R}$ & $\mathrm{S}$ & $\mathrm{S}$ & $S$ & $S$ & $\mathrm{~S}$ & $\mathrm{~T}$ & $\mathrm{~T}$ & $\mathrm{~T}$ & $\mathrm{~T}$ & $\mathrm{~T}$ & $\mathrm{~T}$ & $\mathrm{~T}$ & $\overline{\mathrm{T}}$ \\
\hline $\mathrm{N} 2$ & P70-0-28 & P70-3-20 & $\mathrm{D}$ & $\mathrm{D}$ & $\mathrm{D}$ & $\mathrm{D}$ & $\mathrm{D}$ & $\mathrm{P}$ & $\mathrm{P}$ & Q & Q & $\mathrm{R}$ & $\mathrm{R}$ & $\mathrm{R}$ & $\mathrm{R}$ & $\mathrm{R}$ & $S$ & $\mathrm{~S}$ & $\mathrm{~S}$ & $\mathrm{~S}$ & S & S & $\mathrm{S}$ & $S$ \\
\hline
\end{tabular}

Note: in this table, the steel with initial polished surface was marked as $\mathrm{P}$. The w/c ratio of specimen was marked 70 . The chloride content (wt\% of cement) of specimen was marked as 0 and 3. The serial number of specimens was marked as 19, 20, 27, and 28. For example of P70-0-27, P means the steel had polished surface, 70 means the $\mathrm{w} / \mathrm{c}$ ratio of specimen was $0.70,0$ means the chloride content of specimen was $0 \mathrm{wt} \%$ of cement, and 27 means the serial number of specimens was 27. Cycle types were marked as D, P, Q, R, S, and T, which was illustrated in Figure 2.

cement which was much higher than the chloride threshold level for active corrosion.

The experimental process was also presented in Table 1 and the cycle types were shown in Figure 2. The specimens in A-side and B-side were firstly disconnected for two weeks and then were connected for another two weeks. These four weeks were defined as one cycle and 22 cycles were carried out in this study. A two-week duration was selected for both disconnected and connected periods, because it was a sufficient amount of time for the recovery and stabilization of steel corrosion state during the disconnected period and was also suitable for the stabilization of macrocell current and macrocell polarization during the connected period.

For Case N1, from 1st to 6th cycle (Cycle D), both specimens in A-side and B-side were exposed to the air, from 7 th to 9th cycle (Cycle R), four small holes of specimen in B-side were filled with $3.0 \mathrm{~mol} / \mathrm{L} \mathrm{NO}_{2}{ }^{-}$to increase the nitrite content at the surface of steel in B-side, from 10th to 14th cycle (Cycle S), the nitrite concentration in the four small holes of specimen in B-side was increased to $5.0 \mathrm{~mol} / \mathrm{L}$, and, from 15 th to 22nd cycle (Cycle T), the nitrite concentration in the four small holes of specimen in B-side was increased to $8.0 \mathrm{~mol} / \mathrm{L}$. For case N2, from 1st to 5th cycle (Cycle D), both specimens in A-side and B-side were exposed to the air, from 6th to 7th cycle (Cycle P), four small holes of specimen in B-side were filled with $0.25 \mathrm{~mol} / \mathrm{L} \mathrm{NO}_{2}{ }^{-}$to increase the nitrite content at the surface of steel in B-side, from 8th to 9th cycle (Cycle Q), the nitrite concentration in the four small holes of specimen in B-side was increased to $1.0 \mathrm{~mol} / \mathrm{L}$, from 10th to 14 th cycle (Cycle R), the nitrite concentration in the four small holes of specimen in B-side was increased to $3.0 \mathrm{~mol} / \mathrm{L}$, and from 15 th to 22nd cycle (Cycle S), the nitrite concentration in the four small holes of specimen in B-side was increased to $5.0 \mathrm{~mol} / \mathrm{L}$.

During the process of experiments, the half-cell potential $\left(E_{\text {corr }}\right)$ referred to the $\mathrm{Ag} / \mathrm{AgCl}$ electrode and the resistance of reinforcing steel (unit: $\Omega$ ) and resistance of mortar (unit: $\Omega$ ) were measured at set intervals using the CM-SE1, which is a device developed by Nippon Steel Techno Research for corrosion detection. Since the current imposed by the device was not uniformly distributed on the surface of steel and was greatly affected by the thickness of concrete cover and the diameter of reinforcing steel, the resistance of steel (unit: $\mathrm{k} \Omega \cdot \mathrm{cm}^{2}$ ) and resistance of mortar (unit: $\mathrm{k} \Omega \cdot \mathrm{cm}^{2}$ ) were a function of concrete cover thickness and steel diameter. In this study, they were calculated by the auxiliary software of this device, which fully considered the influence of concrete cover thickness and steel diameter. Before the measurement, water-saturated cotton was placed between the electrode of device and the surface of specimen to ensure good current transmission.

For the purpose of this study and following the convention used in practice, microcell corrosion is the term given to the situation where active dissolution and the corresponding cathodic half-cell reaction take place at adjacent parts of the metal part. For the reinforcing steel embedded in chloridecontaminated concrete, this process always occurs in practice, for example, in specimens in the laboratory containing a single bar and in structures reinforced with a single rebar mat. As was shown in this paper, it was the dominant corrosion process in the periods when the steel in A-side was disconnected with that in B-side. Macrocell corrosion can occur when the actively corroding steel is coupled to another steel which is passive or has a lower corrosion rate, because of either its different composition or environment. As was shown in this paper, it was the situation that the steel in Aside was connected with that in B-side.

In order to distinguish the microcell corrosion current density and the macrocell corrosion current density and to better understand the relationship between them, the corrosion current density of steel in the disconnected periods was defined as the microcell corrosion current density of steel [23-26]. It was calculated by the use of the Stern-Geary equation: $i_{\mathrm{mi}}=B / R p$, where $R p$ was the resistance of steel and $B$ was a constant which was commonly considered to be $26 \mathrm{mV}$ for steel in corroded state and $52 \mathrm{mV}$ for steel in passive state.

In the connected periods of each cycle, the macrocell current flowing between A-side and B-side was measured by zero resistance ammeters (ZRA). The macrocell corrosion current density of steel was calculated by the equation: $i_{\text {ma }}=I_{\mathrm{ma}} / A_{\mathrm{a}}$, where $I_{\mathrm{ma}}$ was the macrocell current (unit: $\mu \mathrm{A}$ ) and $A_{\mathrm{a}}$ (unit: $\mathrm{cm}^{2}$ ) was the surface area of steel that acted as an anode specimen. The anode specimen was defined as the specimen that produced electrons and could be judged from the direction of current flow. The direct measurement of macrocell current had been used effectively by some researchers. It had the advantage that the current measured was naturally flowing and did not result from the perturbation of the system. Its main disadvantage was that the current flowing within either of the two electrodes was not included and thus the measured macrocell current might be less than the true corrosion current. For some conditions, this effect could be significant, notably when the resistance of the concrete or mortar was too high to support 


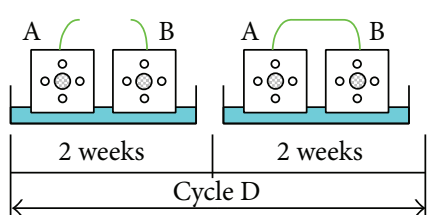

Holes of B are filled with $3.0 \mathrm{M} \mathrm{NO}_{2}^{-}$

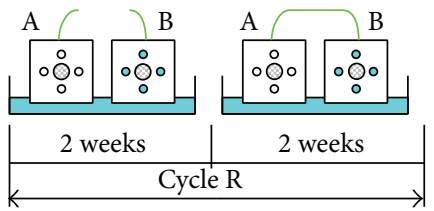

Holes of $\mathrm{B}$ are filled with $0.25 \mathrm{M} \mathrm{NO}_{2}{ }^{-}$

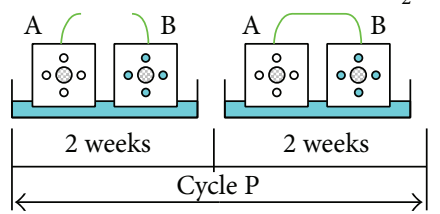

Holes of B are filled with $5.0 \mathrm{M} \mathrm{NO}_{2}{ }^{-}$

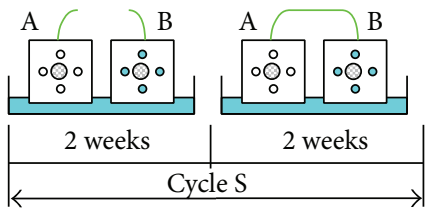

Holes of $\mathrm{B}$ are filled with $1.0 \mathrm{M} \mathrm{NO}_{2}{ }^{-}$

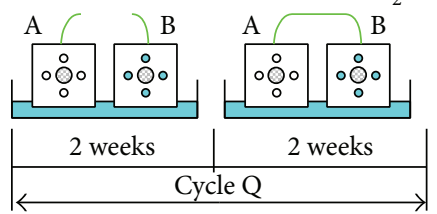

Holes of $\mathrm{B}$ are filled with $8.0 \mathrm{M} \mathrm{NO}_{2}{ }^{-}$

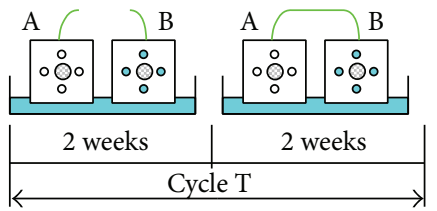

FIGURE 2: Experimental process and cycle types in this study.

the macrocell activity. For this reason, the specimens in Aside and B-side were partially immersed in water to enhance the electroconductivity of mortar $[21,22]$.

\section{Results and Discussion}

3.1. Time Evolution Curves of Half-Cell Potential and Corrosion Current Density. The time evolution curves of halfcell potential $\left(E_{\text {corr }}\right)$, microcell current density, macrocell current density of steels, and the resistance of mortars for the cases designed in Table 1 were shown in Figure 3. For Case N1 as shown in Figure 3(a), the steel in A-side was in passive state and acted as cathode while the steel in B-side was in active corrosion state and acted as anode. So in the disconnected state, it could be found that there was a great difference of half-cell potential, microcell current density between specimen in A-side and specimen in B-side. The gradual increase of nitrite concentration at the surface of steel in B-side by filling the four small holes of mortar with $\mathrm{NaNO}_{2}$ solution was helpful to investigate the effect of nitrite ions on the microcell and macrocell corrosion behaviors of anodic steel. From 1st to 6th cycle (Cycle D), both the small holes of specimens in A-side and B-side were not filled with any solutions. In the disconnected sate, the half-cell potentials of cathode and anode were about -49 and $-412 \mathrm{mV}$, respectively, while the microcell current density of cathode and anode was about 0.0023 and $0.0632 \mu \mathrm{A} / \mathrm{cm}^{2}$, respectively. When the cathode was connected with anode, the macrocell circuit between cathode and anode was formed; the electrons released by the anode were transferred to and consumed by the cathode, which led to the formation of macrocell current flowing from cathode to anode and resulted in the remarkable decrease of half-cell potential of cathode from -49 to $-383 \mathrm{mV}$ and the slight increase of half-cell potential of anode from -412 to $-396 \mathrm{mV}$. The slight increase of half-cell potential of anode and the remarkable decrease of half-cell potential of cathode indicated that the anode was so active that the electrons produced by anode were much greater than the electrons consumed by cathode. The macrocell current flowing between cathode and anode was about $0.405 \mu \mathrm{A} / \mathrm{cm}^{2}$ in the 1st cycle and gradually decreased to $0.200 \mu \mathrm{A} / \mathrm{cm}^{2}$ with the increasing of mortar resistance from $20 \mathrm{k} \Omega \cdot \mathrm{cm}^{2}$ to $70 \mathrm{k} \Omega \cdot \mathrm{cm}^{2}$. From 7 th to 9 th cycle (Cycle R), four small holes of specimen in B-side (anode) were filled with $3 \mathrm{~mol} / \mathrm{L}$ $\mathrm{NO}_{2}{ }^{-}$, which could increase the nitrite concentration at the surface of steel in B-side (anode) by the diffusion and penetration of nitrite ions. It was well known that nitrite ions could promote the formation of a less porous and more compact passive layer $[5,6]$, inhibit the anodic reactions, and decrease the rate of anode to produce electrons. So the presence of nitrite ions on the surface of anode should lead to the increase of half-cell potential toward the electropositive direction and the decrease of microcell current density of anode $[7,8]$. However, seen from the experimental results as shown in Figure 3(a), after filling $3 \mathrm{~mol} / \mathrm{L} \mathrm{NO}_{2}{ }^{-}$into the four small holes of anode in the connected periods of 6th cycle, the half-cell potential of anode firstly decreased from $-410 \mathrm{mV}$ in the disconnected state of 6 th cycle to $-590 \mathrm{mV}$ in the disconnected state of $7 \mathrm{th}$ cycle and then gradually increased to $-440 \mathrm{mV}$ in the disconnected state of 8 th cycle and $-400 \mathrm{mV}$ in the disconnected state of 9th cycle. While the microcell current density of anode firstly increased from $0.063 \mu \mathrm{A} / \mathrm{cm}^{2}$ in the disconnected state of 6 th cycle to $0.228 \mu \mathrm{A} / \mathrm{cm}^{2}$ in the disconnected state of $7 \mathrm{th}$ cycle and then gradually decreased to $0.19 \mu \mathrm{A} / \mathrm{cm}^{2}$ in the disconnected state of 8 th cycle and $0.18 \mu \mathrm{A} / \mathrm{cm}^{2}$ in the disconnected state of 9th cycle. Corresponding to the change of half-cell potential and microcell current density of anode, some changes on the macrocell current density also could be observed. The macrocell current density of anode firstly increased from $0.2 \mu \mathrm{A} / \mathrm{cm}^{2}$ in the connected state of 6 th cycle to $0.35 \mu \mathrm{A} / \mathrm{cm}^{2}$ in the connected state of 7 th cycle and then gradually decreased to $0.06 \mu \mathrm{A} / \mathrm{cm}^{2}$ in the connected state of 8 th cycle and $0.03 \mu \mathrm{A} / \mathrm{cm}^{2}$ in the connected state of 9 th cycle. It should be noted that filling $3 \mathrm{~mol} / \mathrm{L} \mathrm{NO}_{2}{ }^{-}$into the holes of anode in 7th 9th cycle promoted the increase of macrocell potential difference of anode during the disconnected and connected periods and the decrease of macrocell potential difference of cathode during the disconnected and connected periods. From 10th to 14th cycle (Cycle S), the concentration of nitrite solution in the four small holes of specimen in B-side 


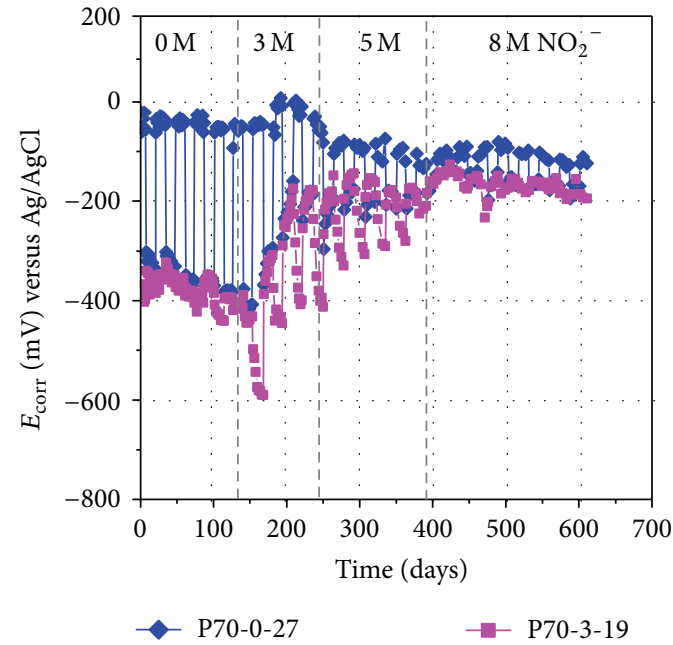

(a)

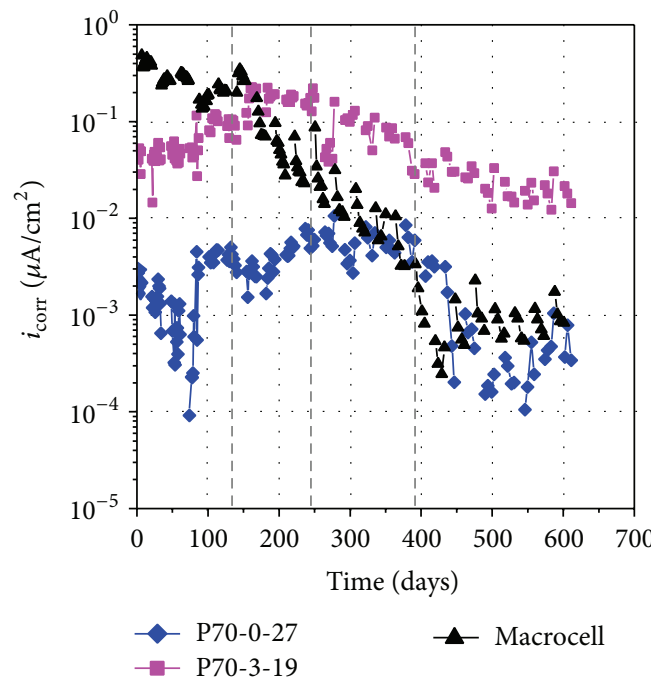

(c)

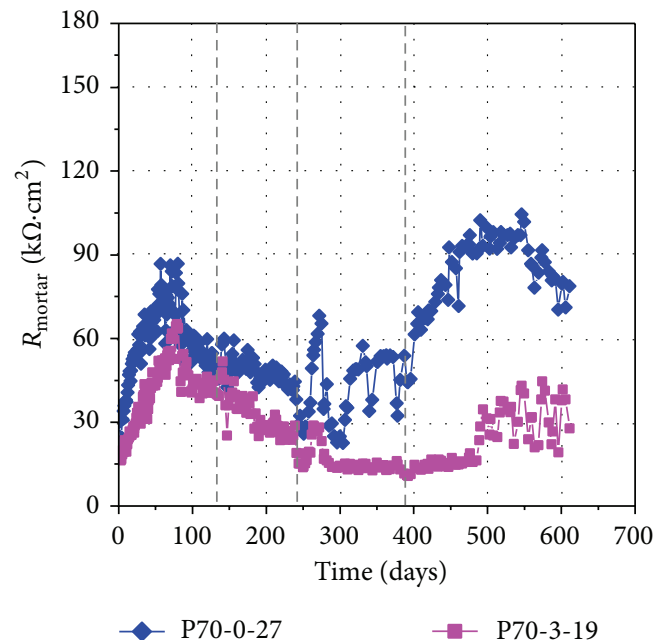

(e)

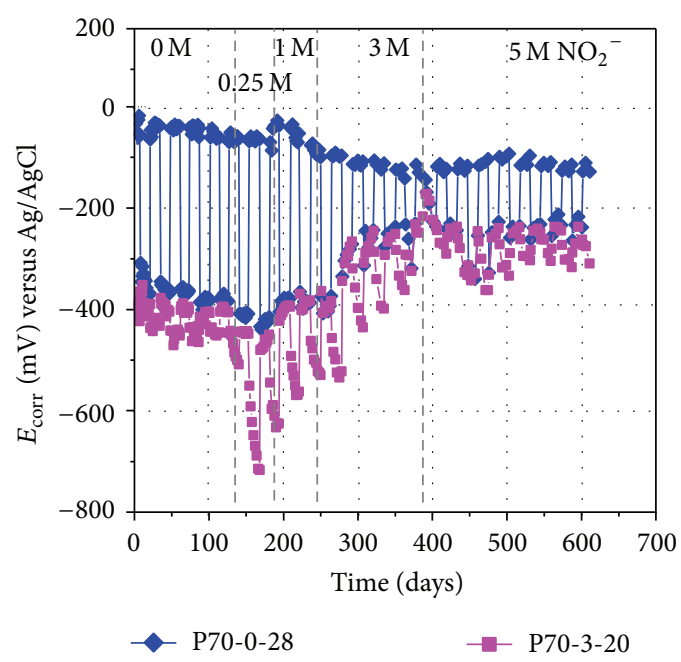

(b)

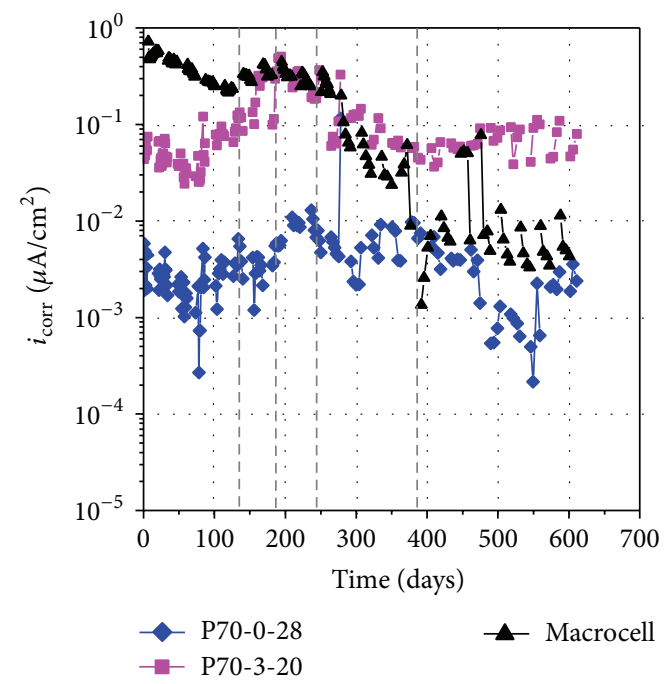

(d)

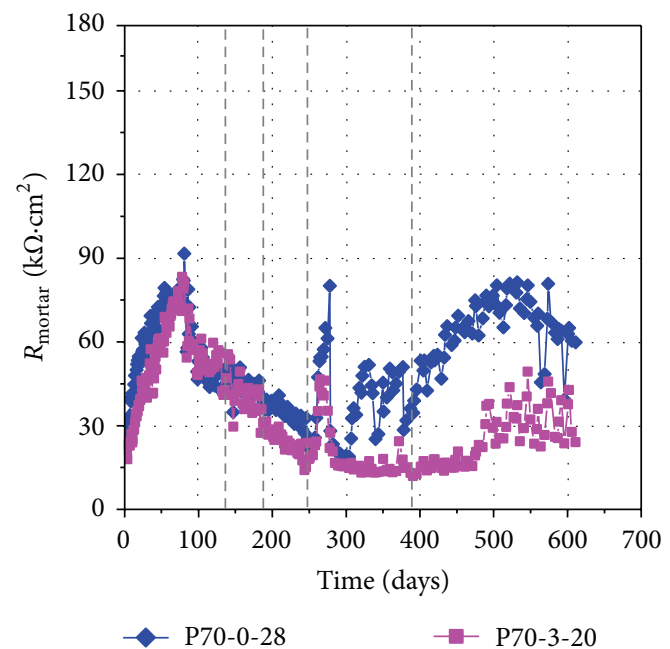

(f)

FIGURE 3: Time evolution curves of half-cell potential, microcell current density, macrocell current density, and resistance of mortars. (a) Half-cell potential of steel in Case N1, (b) half-cell potential of steel in Case N2, (c) corrosion current density of steel in Case N1, (d) corrosion current density of steel in Case N2, (e) resistance of mortar in Case N1, and (f) resistance of mortar in Case N2. 
(anode) was increased to $5 \mathrm{~mol} / \mathrm{L} \mathrm{NO}_{2}{ }^{-}$, which accelerated the diffusion and penetration rate of nitrite duo to the greater concentration difference and therefore led to the further increase of half-cell potential of anode in the disconnected state, the decrease of microcell current density of anode in the disconnected state, and the great decrease of macrocell current density in the connected state. The half-cell potential of anode was increased to $-280 \mathrm{mV}$ in the disconnected state of 14th cycle while the microcell current density and macrocell current density were decreased to 0.067 and $0.008 \mu \mathrm{A} / \mathrm{cm}^{2}$, respectively. From 15th to 22nd cycle (Cycle $\mathrm{T})$, the concentration of nitrite solution in the four small holes of specimen in B-side (anode) was further increased to $8 \mathrm{~mol} / \mathrm{L} \mathrm{NO}_{2}{ }^{-}$, which greatly accelerated the diffusion and penetration rate of nitrite. The half-cell potential of anode in the disconnected state was finally increased to $-180 \mathrm{mV}$ while the microcell current density and macrocell current density were finally decreased to 0.018 and $0.0008 \mu \mathrm{A} / \mathrm{cm}^{2}$, respectively. Based on the above results, the effectiveness of nitrite ions in shifting the corrosion potential towards electropositive direction and reducing the corrosion rate of anodic steel was confirmed.

Additionally, during the whole experimental process, the condition of cathode was kept constant while the condition of anode was changed by filling nitrite solution with various concentration into the four holes around anodic steel. So the ability of cathode to consume the electrons was constant, and the macrocell current flowing between cathode and anode was determined by the ability of anode to release the electrons. The presence of nitrite on the surface of anode could inhibit the anodic reaction of anode and weaken the ability of anode to produce the electrons. According the experimental results, the macrocell current flowing between cathode and anode was gradually decreased with the increasing of nitrite concentration on the surface of anode. This not only confirmed the inhibiting efficiency of nitrite on macrocell corrosion but also indicated that the corrosion was controlled by the anodic reaction of anode.

The initial and final concentrations of nitrite solution filled into the holes of anode in Case N2 were different from that of Case $\mathrm{N} 1$ and therefore led to the different results. The initial concentrations of nitrite in Case N2 and Case $\mathrm{N} 1$ were 0.25 and $3 \mathrm{~mol} / \mathrm{L}$. Filling initial $0.25 \mathrm{~mol} / \mathrm{L} \mathrm{NO}_{2}{ }^{-}$ in Case N2 resulted in the decrease of half-cell potential of anode from -446 to $-717 \mathrm{mV}$ and the increase of microcell current density of anode from 0.078 to $0.31 \mu \mathrm{A} / \mathrm{cm}^{2}$ and the increase of macrocell current density of anode from 0.23 to $0.39 \mu \mathrm{A} / \mathrm{cm}^{2}$, and the time taken for the corrosion rate of anode in Case N2 to reach the highest value was about 60 days. Compared with Case N2, the initial concentration of nitrite solution filled into the four small holes around anode in Case N1 was $3 \mathrm{~mol} / \mathrm{L}$ and was 12 times higher than that of Case N2. After filling initial $3 \mathrm{~mol} / \mathrm{L} \mathrm{NO}_{2}{ }^{-}$in Case N1, the half-cell potential of anode was decreased from -410 to $-590 \mathrm{mV}$, the microcell current density of anode was increased from 0.063 to $0.228 \mu \mathrm{A} / \mathrm{cm}^{2}$ and the macrocell current density of anode was also increased from 0.20 to $0.35 \mu \mathrm{A} / \mathrm{cm}^{2}$. The time taken for the corrosion rate of anode in Case N1 to reach the highest value was about 4 days and much shorter than that of Case N2. Analyzed from these data, the following conclusions could be obtained. Firstly, in the early stage of nitrite diffusing to the surface of anode contaminated by chloride, the corrosion of anodic steel would be accelerated. Secondly the increase degree of corrosion rate was affected by the initial nitrite concentration. In other words, the lower nitrite concentration had a higher risk to accelerate the chloride-induced corrosion of anode in the early stage, which was consistent with the concern on nitrite ions that insufficient content could exacerbate corrosion rather than reduce it [27]. It should be emphasized that the risk of nitrite to accelerate the chloride-induced corrosion of anode only happened in the early stage of nitrite diffusing to the surface of anode, and the time taken for the corrosion rate of anode to reach the highest value greatly depended on the initial concentration of nitrite. As the nitrite concentration at the surface of anode continued to increase, the ability of nitrite to inhibit corrosion was gradually enhanced, which could lead to the decrease of corrosion rate of anode. The decrease degree of corrosion rate of anode mainly depended on the final concentration of nitrite. By filling the final $5 \mathrm{~mol} / \mathrm{L} \mathrm{NO}_{2}{ }^{-}$in Case N2, the half-cell potential of anode was finally increased to $-310 \mathrm{mV}$ and the microcell current density of anode finally reached $0.082 \mu \mathrm{A} / \mathrm{cm}^{2}$ and the macrocell current density of anode was finally decreased to $0.0044 \mu \mathrm{A} / \mathrm{cm}^{2}$. By filling the final $8 \mathrm{~mol} / \mathrm{L} \mathrm{NO}_{2}{ }^{-}$in Case N1, the half-cell potential of anode was finally increased to $-180 \mathrm{mV}$ and the microcell current density of anode was finally reached to $0.018 \mu \mathrm{A} / \mathrm{cm}^{2}$ and the macrocell current density of anode was finally decreased to $0.0008 \mu \mathrm{A} / \mathrm{cm}^{2}$. The corrosion rate of anode in Case N1 with the final $8 \mathrm{~mol} / \mathrm{L} \mathrm{NO}_{2}{ }^{-}$was much lower than that in Case N2 with the final $5 \mathrm{~mol} / \mathrm{L} \mathrm{NO}_{2}{ }^{-}$, which indicated that the final nitrite concentration had a significant influence in decreasing the microcell and macrocell current density; the higher the final nitrite concentration was the lower the microcell and macrocell current density were expected.

The decrease of half-cell potential and the increase of corrosion current density of anode after filling nitrite solution into the four small holes of anode might be attributed to the increase of moisture and chloride content at the surface of anodic steel. The reason for high moisture to decrease the half-cell potential and change the corrosion rate of steel had been well analyzed in literature [28, 29], so here the analysis was mainly focused on the reason of the increase of chloride content. It was well documented in literatures $[30,31]$ that chloride ions could be present in mortar in the form of chemically bound chloride, physically adsorbed chloride on the pore walls, and free chloride in the pore solution. Because the bound and adsorbed chloride were relatively immobile and might not be transported to the steel surface, only the free chloride contributed to the corrosion process. The degree of chloride binding depended on many factors, such as the quantity of the tricalcium aluminate phase $\left(\mathrm{C}_{3} \mathrm{~A}\right)$ in the cement, the $\mathrm{pH}$ value of pore solution, the cation of chloride salt, and the quantity of nitrite ions. Under the action of $\mathrm{C}_{3} \mathrm{~A}, \mathrm{pH}$, cation, and nitrite, the free chloride 
content in the pore solution would be increased or decreased. In this study, filling nitrite solution into the holes of mortar could greatly increase the free nitrite content of pore solution but had little influence on the quantity of $\mathrm{C}_{3} \mathrm{~A}$, the $\mathrm{pH}$ value of pore solution, and the cation of chloride salt. Since the nitrite ions could also be bound by cement hydration products and was affected by the cement composition, $\mathrm{pH}$, the chloride concentration, and the cation of nitrite salt [32], there was a clear competition for adsorption sites between nitrite and chloride, which suggested that the presence of nitrite ions in pore solution would lead to the transformation of bound chloride. The bound chlorides at the steel surface would be released to form the free chlorides and therefore resulted in the increase of free chloride concentration. The increase of free chloride concentration could accelerate the dissolution rate of anode and thus lead to the decrease of halfcell potential of anode and the increase of corrosion current density. So in the early stage of filling nitrite solution into the holes of mortar, the mole ratio of nitrite to chloride was very low and the rate of nitrite ions to inhibit corrosion was much lower than the rate of chloride ions to accelerate corrosion. However, due to the gradual accumulation of nitrite in pore solution, the mole ratio of nitrite to chloride would gradually increase, which led to the increase of the rate of nitrite to passivate the steel and the decrease of the rate of chloride to dissolve the steel [17]. So in the later stage of filling nitrite solution into the holes of mortar, with the increasing of mole ratio of nitrite to chloride, the corrosion of anode would be inhibited and led to the increase of half-cell potential of anode and the decrease of corrosion current density.

\subsection{Effect of Nitrite Ions on the Relationships between $\Delta E_{\text {corr }}$} and Macrocell Current Density. For macrocell corrosion, the potential difference between anodic and cathodic was one of the important factors to affect the macrocell current. In order to better understand the effect of nitrite ions on the macrocell current, the relationship between potential difference and the macrocell current density was investigated. The definition of potential difference was given in Figure 4 . The $\Delta E_{\text {corr }} 1$ was defined as the potential difference between cathode and anode during the disconnected periods, and $\Delta E_{\text {corr }} 4$ was the potential difference between cathode and anode during the connected periods. While $\Delta E_{\text {corr }} 2$ was the potential difference of cathodic steel during the disconnected periods and connected periods and $\Delta E_{\text {corr }} 3$ was the potential difference of anodic steel during the disconnected periods and connected periods, the influences of nitrite concentrations on the relationships between $\Delta E_{\text {corr }} n(n=1,2,3)$ and the macrocell current density were presented in Figures 5 and 6.

Seen form these figures, firstly it could be confirmed that the presence of nitrite had a significant influence on the $\Delta E_{\text {corr }} n(n=1,2,3)$ and the macrocell current density. For chloride induced corrosion, low nitrite concentration (such as 0.25 and $1.0 \mathrm{~mol} / \mathrm{L}$ ) could lead to the increase of $\Delta E_{\text {corr }} 1$ and $\Delta E_{\text {corr }} 3$ and the increase of macrocell current density, while high nitrite concentration (such as 5.0 and $8.0 \mathrm{~mol} / \mathrm{L}$ ) not only led to the significant decrease of the $\Delta E_{\text {corr }} n(n=1,2,3)$ but also resulted in the remarkable

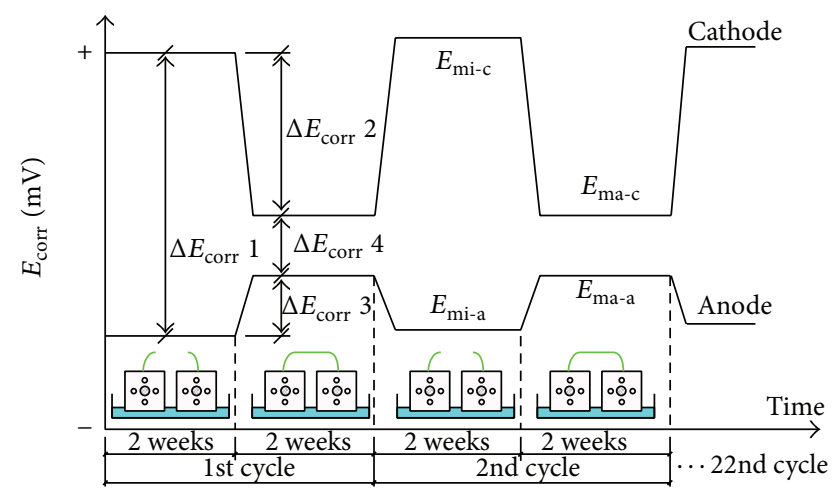

$$
\begin{aligned}
& \Delta E_{\text {corr }} 1=/ E_{\text {mi-a }}-E_{\text {mi-c }} / \quad \Delta E_{\text {corr }} 2=/ E_{\text {mi-c }}-E_{\text {ma-c }} / \\
& \Delta E_{\text {corr }} 3=/ E_{\text {mi-a }}-E_{\text {ma-a }} / \quad \Delta E_{\text {corr }} 4=/ E_{\text {ma-c }}-E_{\text {ma-a }} / \\
& \text { Polarization ratio of steel in cathode }=\Delta E_{\text {corr }} 2 / \Delta E_{\text {corr }} 1 \\
& \text { Polarization ratio of steel in anode }=\Delta E_{\text {corr }} 3 / \Delta E_{\text {corr }} 1
\end{aligned}
$$

FIGURE 4: Definition of potential difference of macrocell corrosion.

decrease of macrocell current density. The effectiveness of adequate nitrite ions to inhibit the macrocell current could be confirmed.

3.3. Effect of Nitrite Ions on the Macrocell Polarization Ratios of Cathode and Anode. In the macrocell corrosion state, it was important to know the relative contributions from the polarization of the cathode, anode, and the mortar resistance, as described by $\Delta E_{\text {corr }} 1=\Delta E_{\text {corr }} 2+\Delta E_{\text {corr }} 3+\Delta E_{\text {corr }} 4$, which had been graphically illustrated previously [22]. In order to obtain the relative contributions of $\Delta E_{\text {corr }} n(n=2,3,4)$ on $\Delta E_{\text {corr }} 1$ for the cases with various nitrite concentrations, the relationships between $\Delta E_{\text {corr }} 1$ and $\Delta E_{\text {corr }} n(n=2,3,4)$ were plotted in Figure 7 and were fitted by the linear function. The slopes of the lines were defined as the macrocell polarization ratio of cathode, the macrocell polarization ratio of anode, and the macrocell polarization ratio of mortar resistance, respectively.

The influences of nitrite concentrations on the macrocell polarization ratios of cathode, anode, and mortar resistance were summarized in Figure 8. It was found that nitrite had a significant influence on the macrocell polarization ratios of cathode and anode. With the absence of nitrite ions, the macrocell polarization ratio of cathode was much higher than 0.8 , and the macrocell polarization ratio of anode was lower than 0.1 . The presence of nitrite ions on the surface of anodic steel could effectively weaken the kinetics of anodic reactions and therefore result in the increase of macrocell polarization ratio of anode and the decrease of macrocell polarization ratio of cathode.

\subsection{Effect of Nitrite Ions on the Macrocell Polarization Slopes of} Cathode and Anode. The macrocell polarization slope of the cathode (anode) had been defined in the macrocell corrosion model proposed by Maruya et al. [25] as shown in Figure 9. The macrocell polarization slope of cathode was marked as $\beta_{\text {ma-c }}$, while the macrocell polarization slope of anode 


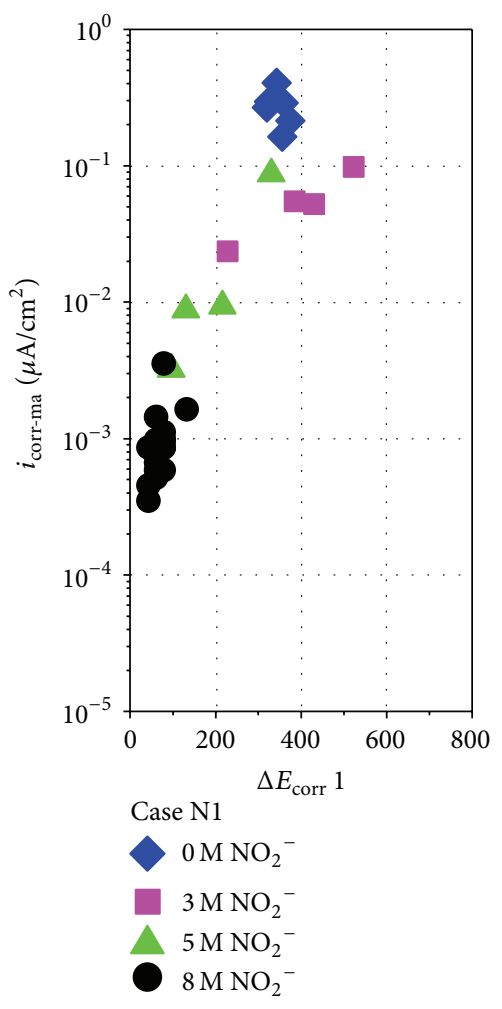

(a)

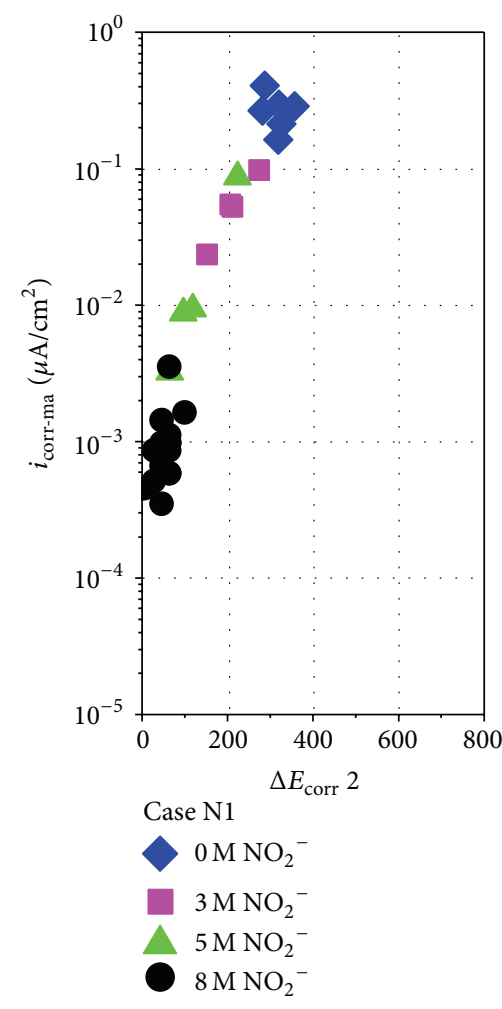

(b)

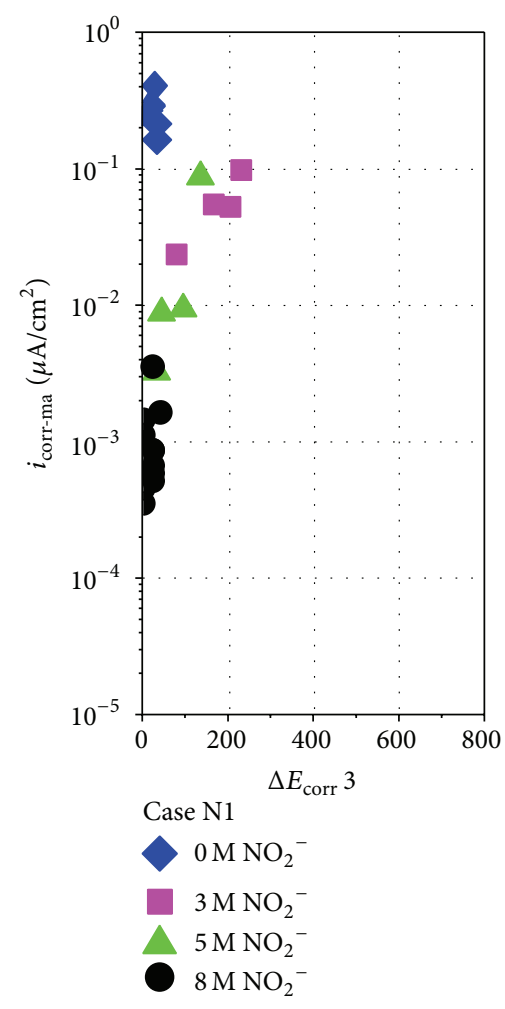

(c)

FIGURE 5: Effect of nitrite concentrations on the (a) relationships between $\Delta E_{\text {corr }} 1$ and macrocell current density, (b) relationships between $\Delta E_{\text {corr }} 2$ and macrocell current density, and (c) relationships between $\Delta E_{\text {corr }} 3$ and macrocell current density, for the Case N1.

was marked as $\beta_{\text {ma-a }}$. The $\beta_{\text {ma-c }}$ or $\beta_{\text {ma-a }}$ can be calculated by the two points that represented the corrosion state of the cathodic or anodic steel in microcell corrosion state $\left(\left(i_{\text {mi-c }}, E_{\text {mi-c }}\right)\right.$ or $\left.\left(i_{\text {mi-a }}, E_{\text {mi-a }}\right)\right)$ and macrocell corrosion state $\left(\left(i_{\text {ma }}, E_{\text {ma-c }}\right)\right.$ or $\left.\left(i_{\text {ma }}, E_{\text {ma-a }}\right)\right)$. The value of the point that represented the corrosion state of cathodic (anodic) steel in microcell corrosion state was obtained by averaging the halfcell potential and the microcell current density obtained in the disconnected periods, while the value of the point that represented the corrosion state of cathodic (anodic) steel in macrocell corrosion state was obtained by averaging the halfcell potential and the macrocell current density obtained in the connected periods.

The macrocell polarization slopes of cathode $\left(\beta_{\text {ma-c }}\right)$ and anode $\left(\beta_{\text {ma-a }}\right)$ could reflect the polarization ability of cathode and anode in the macrocell corrosion state [22]. The higher the $\beta_{\text {ma-c }}$, the stronger the ability of the cathode to receive the electrons, which results in a lower macrocell polarization resistance of the cathode. The lower the $\beta_{\text {ma-a }}$, the stronger the ability of anode to produce the electrons, which results in a lower macrocell polarization resistance of the anode. In order to better understand the effect of nitrite contents on the macrocell polarization slopes of cathode and anode, the macrocell polarization angles of cathode $\left(\theta_{c}\right)$ and anode $\left(\theta_{\mathrm{a}}\right)$ were used instead of the $\beta_{\text {ma-c }}$ and $\beta_{\text {ma-a }}$. Due to the relationships that $\beta_{\text {ma-c }}=-\tan \left(\theta_{\mathrm{c}}\right)$ and $\beta_{\text {ma-a }}=\tan \left(\theta_{\mathrm{a}}\right)$, the macrocell polarization angles of cathode $\left(\theta_{\mathrm{c}}\right)$ and anode $\left(\theta_{\mathrm{a}}\right)$ could be obtained. Theoretically, the higher the $\theta_{c}$, the lower the ability of cathode to consume the electrons, which means the macrocell polarization resistance of cathode is high. The higher the $\theta_{\mathrm{a}}$, the lower the ability of anode to produce the electrons, which means the macrocell polarization resistance of anode is high.

For the cases with various nitrite concentrations, the average values and the standard deviation of macrocell polarization angles of cathode and anode $\left(\theta_{c}\right.$ and $\left.\theta_{a}\right)$ were analyzed statistically based on the data obtained from the first cycle to the last cycle. The results were presented in Figure 10. Seen from these results, it could be observed that, with the gradual increase of nitrite concentration on the surface of anodic steel, both $\theta_{c}$ and $\theta_{a}$ were increased, and the increment of $\theta_{\mathrm{a}}$ was much higher than that of $\theta_{\mathrm{c}}$. As mentioned above, the increase of $\theta_{c}$ means the increase of macrocell polarization resistance of cathode and the increase of $\theta_{\mathrm{a}}$ means the increase of macrocell polarization resistance of anode. It should be noted that the cathode always had the same condition when nitrite concentrations in anode were increased, so in theory, the $\theta_{c}$ should be constant and was not affected by the nitrite contents of anode. The increase of $\theta_{c}$ means the increase of macrocell polarization resistance of cathode, which might result from the increase of mortar resistance of cathode and was not caused by the presence of nitrite in anode. According to the study of López and González [29], the polarization resistance of 


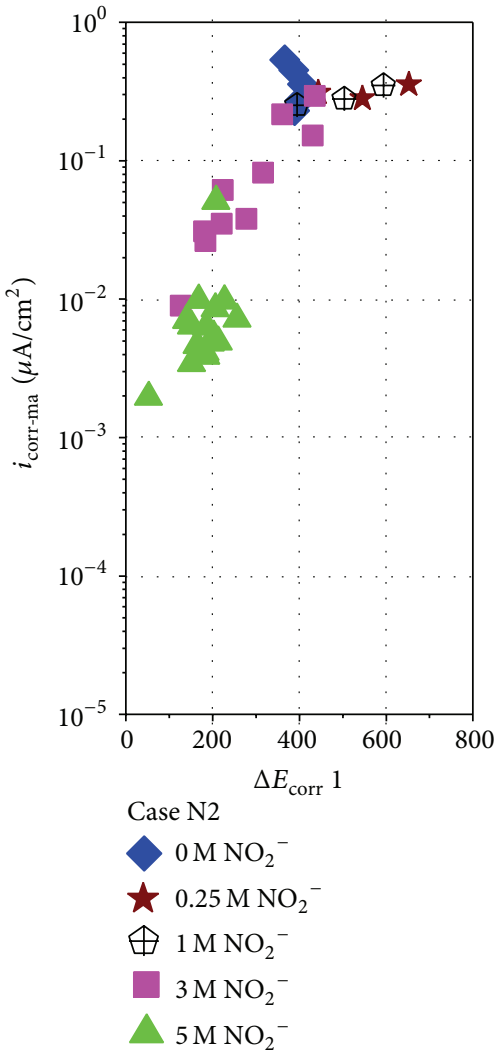

(a)

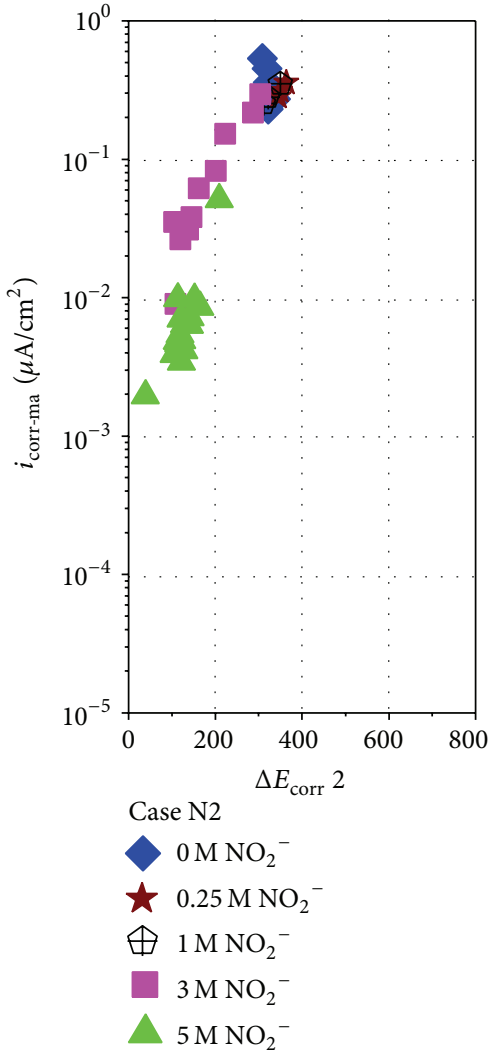

(b)

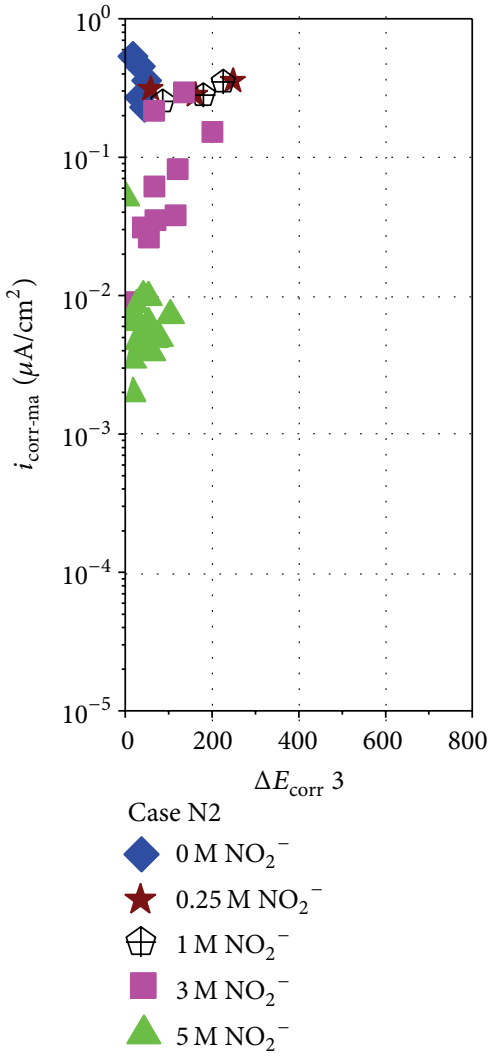

(c)

FIGURE 6: Effect of nitrite concentrations on the (a) relationships between $\Delta E_{\text {corr }} 1$ and macrocell current density, (b) relationships between $\Delta E_{\text {corr }} 2$ and macrocell current density, and (c) relationships between $\Delta E_{\text {corr }} 3$ and macrocell current density, for the Case N2.

steel was proportional to the mortar resistance. Filling nitrite solution into the holes of anode could lead to the decrease of mortar resistance of anode and therefore result in the decrease of macrocell polarization resistance of anode. So in theory, the $\theta_{\mathrm{a}}$ should be decreased. However, according to the experimental results, after filling nitrite solution into the holes of anode, the $\theta_{\mathrm{a}}$ was increased rather than being decreased, which means the increase of $\theta_{a}$ resulted from the presence of nitrite. So based on the above analysis, the following conclusions could be obtained. The presence of nitrite on the surface of anode could increase the macrocell polarization angle of anode and had little influence on the macrocell polarization angle of cathode. The effectiveness of nitrite to enhance the macrocell polarization resistance of anode was confirmed.

3.5. Mechanism for Nitrite Ions to Affect the Macrocell Corrosion. In the front parts, the effect of nitrite on the macrocell potential and current density, macrocell polarization ratios, and slopes (angles) of cathode and anode had been investigated and analyzed. Based on these experimental results, the mechanism for nitrite to affect the macrocell corrosion was proposed and illustrated in Figure 11. For the sake of explanation, Case $\mathrm{D}$ (cathode without $\mathrm{Cl}^{-}$and $\mathrm{NO}_{2}{ }^{-}$, anode with high $\mathrm{Cl}^{-}$and without $\mathrm{NO}_{2}{ }^{-}$) and Case $\mathrm{T}$ (cathode without $\mathrm{Cl}^{-}$and $\mathrm{NO}_{2}{ }^{-}$, anode with high $\mathrm{Cl}^{-}$and high $\mathrm{NO}_{2}{ }^{-}$) were defined. In Case D, the mortar around cathode did not contain any chloride and nitrite, while the mortar around anode contained high chloride content but did not contain any nitrite. In microcell corrosion state, half-cell potential and microcell current density of cathode were marked as $E_{\text {mi-c-D }}$ and $i_{\text {mi-c-D }}$, while half-cell potential and microcell current density of anode were marked as $E_{\text {mi-a-D }}$ and $i_{\text {mi-a-D }}$. In macrocell corrosion state, the macrocell polarization angles of cathode and anode were marked as $\theta_{\mathrm{c}-\mathrm{D}}$ and $\theta_{\mathrm{a}-\mathrm{D}}$, respectively, and the macrocell current density was marked as $i_{\text {ma-D }}$.

In the presence of nitrite in the mortar around anode (Case T), nitrite and chloride coexisted on the surface of anodic steel. Due to the ability of nitrite to rehabilitate the passive film that destroyed by chloride, in microcell corrosion state, the half-cell potential of anode could be increased from $E_{\text {mi-a-D }}$ to $E_{\text {mi-a-T }}$ while the microcell current density of anode was decreased from $i_{\text {mi-a-D }}$ to $i_{\text {mi-a-T. }}$. In the macrocell corrosion state, the presence of nitrite had little effect on the macrocell polarization angle of cathode $\left(\theta_{\mathrm{c}-\mathrm{T}}\right.$ was almost equal to $\left.\theta_{c-D}\right)$ but resulted in the great increase of macrocell polarization angle of anode $\left(\theta_{\mathrm{a}-\mathrm{T}}\right.$ was much higher than $\left.\theta_{\mathrm{a}-\mathrm{D}}\right)$. So the mechanism of nitrite to affect the macrocell 


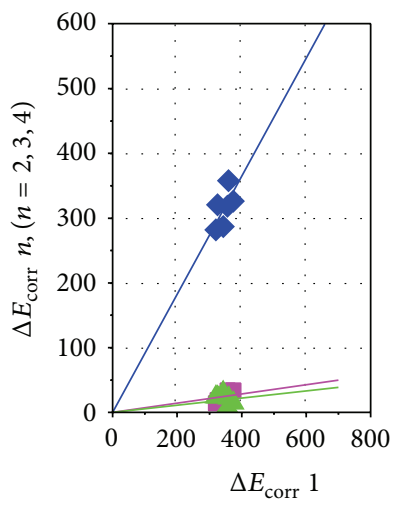

Case $\mathrm{N} 10 \mathrm{M} \mathrm{NO}_{2}$

$\Delta E_{2}=0.9099 * \Delta E_{1}$

$\Delta E_{3}=0.0715 * \Delta E_{1}$

$\Delta \Delta E_{4}=0.0556 * \Delta E_{1}$

(a)

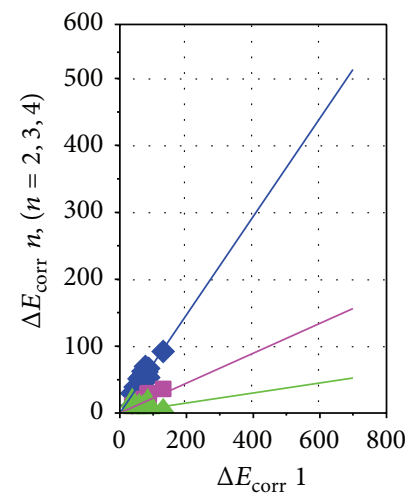

Case $\mathrm{N} 18 \mathrm{M} \mathrm{NO}_{2}$

$$
\Delta E_{2}=0.7332 * \Delta E_{1}
$$

$\Delta E_{3}=0.2232 * \Delta E_{1}$

$\Delta E_{4}=0.0748 * \Delta E_{1}$

(d)

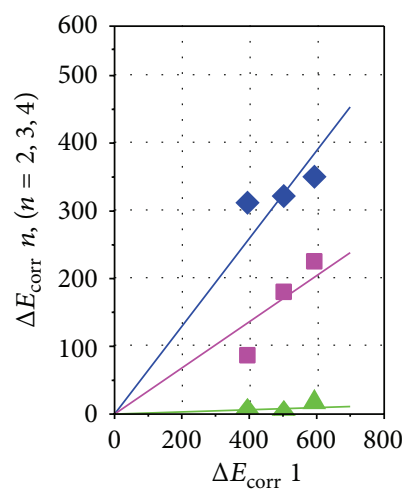

Case $\mathrm{N} 21 \mathrm{M} \mathrm{NO}_{2}{ }^{-}$

$\Delta E_{2}=0.6480 * \Delta E_{1}$

$\Delta E_{3}=0.3404 * \Delta E_{1}$

$\Delta E_{4}=0.0158 * \Delta E_{1}$

(g)

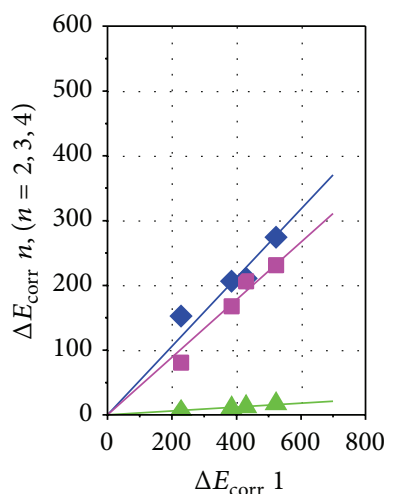

Case $\mathrm{N} 13 \mathrm{M} \mathrm{NO}_{2}$

$\Delta E_{2}=0.5293 * \Delta E_{1}$

$\Delta E_{3}=0.4443 * \Delta E_{1}$

$\Delta \Delta E_{4}=0.0300 * \Delta E_{1}$

(b)

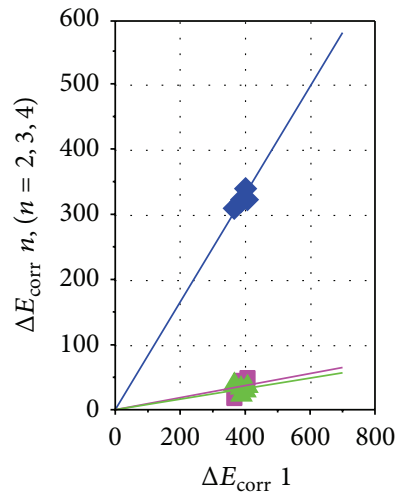

Case $\mathrm{N} 20 \mathrm{M} \mathrm{NO}_{2}{ }^{-}$

$\Delta E_{2}=0.8260 * \Delta E_{1}$

$\Delta E_{3}=0.0927 * \Delta E_{1}$

$\Delta E_{4}=0.0812 * \Delta E_{1}$

(e)

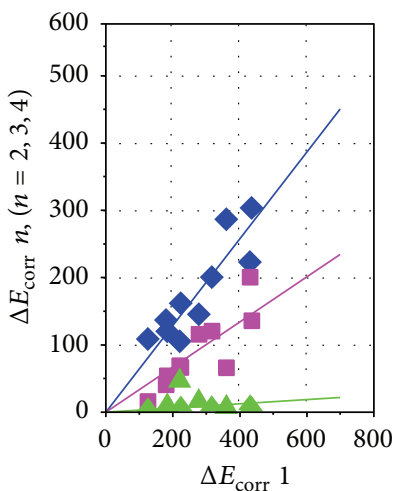

Case N2 $3 \mathrm{M} \mathrm{NO}_{2}$

$\Delta E_{2}=0.6436 * \Delta E_{1}$

$\Delta E_{3}=0.3352 * \Delta E_{1}$

$\Delta E_{4}=0.0311 * \Delta E_{1}$

(h)

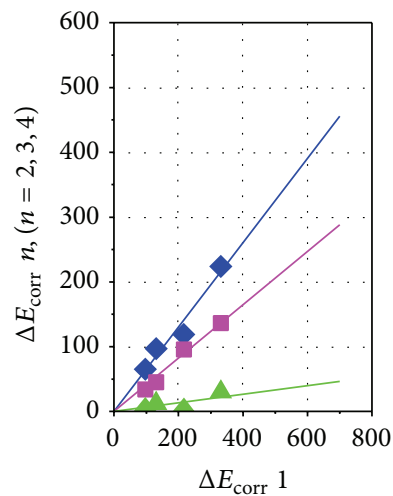

Case N1 $5 \mathrm{M} \mathrm{NO}_{2}$

$\Delta E_{2}=0.6507 * \Delta E_{1}$

$\Delta E_{3}=0.4113 * \Delta E_{1}$

$\Delta \Delta E_{4}=0.0661 * \Delta E_{1}$

(c)

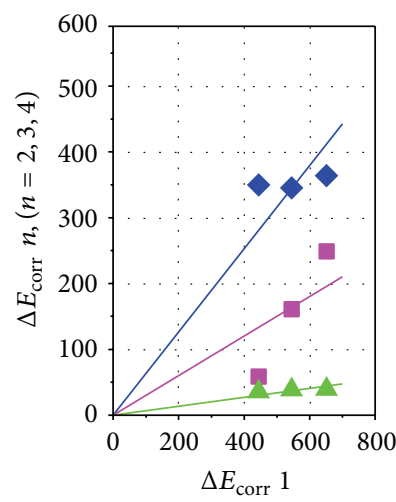

Case $\mathrm{N} 20.25 \mathrm{M} \mathrm{NO}_{2}$

$\Delta \Delta E_{2}=0.6319 * \Delta E_{1}$

$\Delta E_{3}=0.3005 * \Delta E_{1}$

$\Delta E_{4}=0.0676 * \Delta E_{1}$

(f)

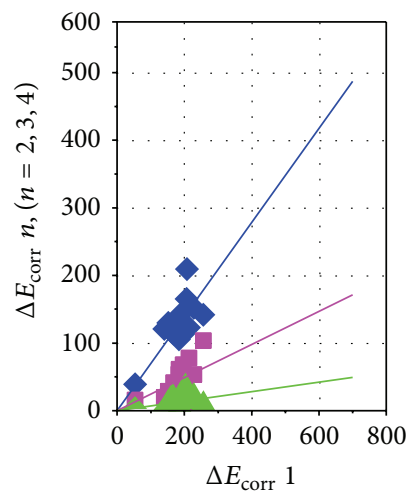

Case $\mathrm{N} 25 \mathrm{M} \mathrm{NO}_{2}{ }^{-}$

$\Delta \Delta E_{2}=0.6964 * \Delta E_{1}$

$\Delta E_{3}=0.2447 * \Delta E_{1}$

$\Delta E_{4}=0.0704 * \Delta E_{1}$

(i)

Figure 7: Relationships between $\Delta E_{\text {corr }} 1$ and $\Delta E_{\text {corr }} n(n=2,3,4)$ for (a) Case N1, 0 mol/L $\mathrm{NO}_{2}{ }^{-}$, (b) Case N1, 3 mol/L NO${ }^{-}$, (c) Case N1, $5 \mathrm{~mol} / \mathrm{L} \mathrm{NO}_{2}{ }^{-}$, (d) Case N1, $8 \mathrm{~mol} / \mathrm{L} \mathrm{NO}_{2}{ }^{-}$, (e) Case N2, $0 \mathrm{~mol} / \mathrm{L} \mathrm{NO}_{2}{ }^{-}$, (f) Case N2, $0.25 \mathrm{~mol} / \mathrm{L} \mathrm{NO}_{2}{ }^{-}$, (g) Case N2, $1 \mathrm{~mol} / \mathrm{L} \mathrm{NO}_{2}{ }^{-}$, (h) Case $\mathrm{N} 2,3 \mathrm{~mol} / \mathrm{L} \mathrm{NO}_{2}{ }^{-}$, and (i) Case $\mathrm{N} 2,5 \mathrm{~mol} / \mathrm{L} \mathrm{NO}_{2}{ }^{-}$. 


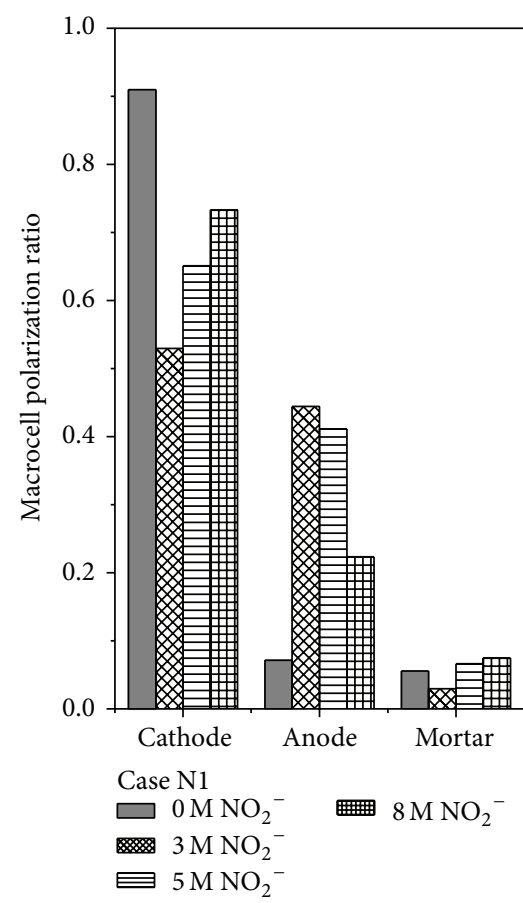

(a)

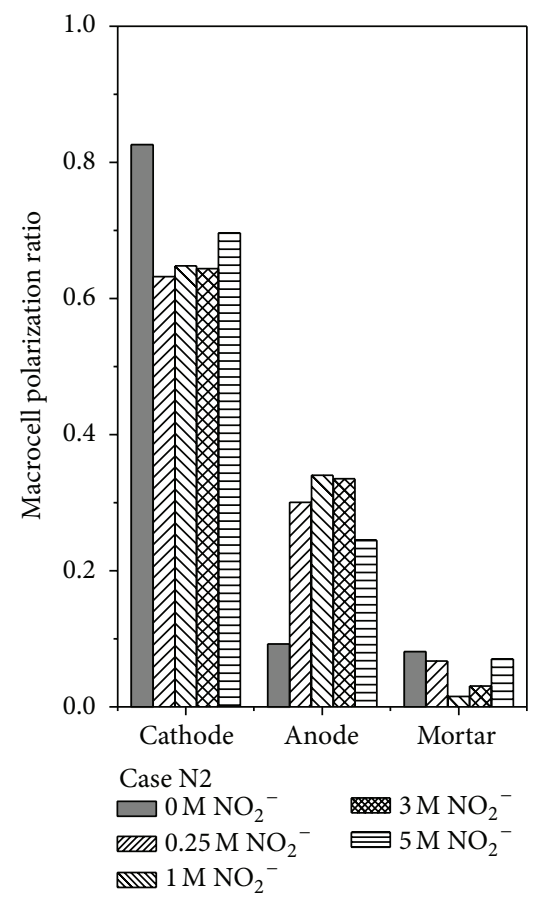

(b)

FIGURE 8: Effect of nitrite concentrations on the macrocell polarization ratios of cathode, anode and mortar. (a) Case N1, (b) Case N2.

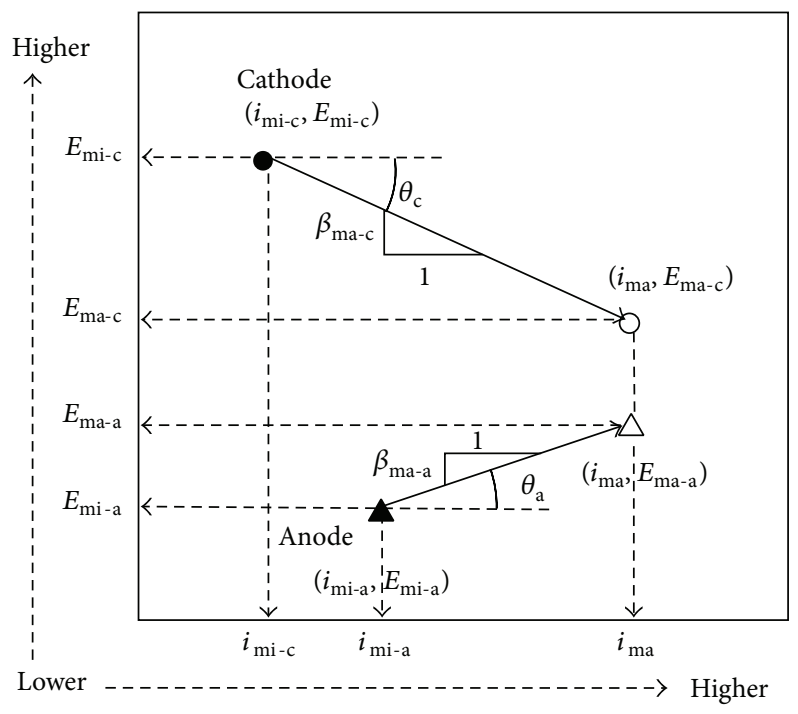

FIGURE 9: Definition of macrocell polarization slopes and angles of cathode and anode [25].

corrosion was that firstly the presence of nitrite on the surface of anode could decrease the driving force of macrocell corrosion (macrocell potential difference between cathode and anode) and lead to the decrease of macrocell current and secondly the macrocell polarization resistance of anode was enhanced by nitrite, which also could lead to the decrease of macrocell current. Therefore, under the combined effect of the decrease of macrocell potential difference and the increase of macrocell polarization resistance of anode, the macrocell current density was decreased from $i_{\text {ma-D }}$ to $i_{\text {ma-T }}$.

\section{Conclusions}

When the cathode was in passive state and the anode was in active corrosion state, the presence of adequate nitrite on the surface of anodic steel could significantly decrease the macrocell current by increasing the resistance of anode and decreasing the macrocell potential difference between cathode and anode.

In macrocell corrosion state, the presence of nitrite had a great influence on the macrocell polarization ratios of 


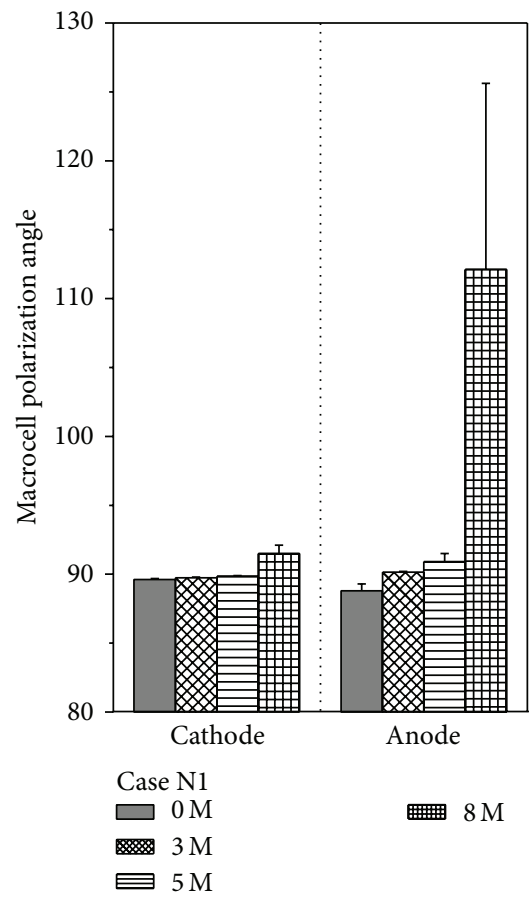

(a)

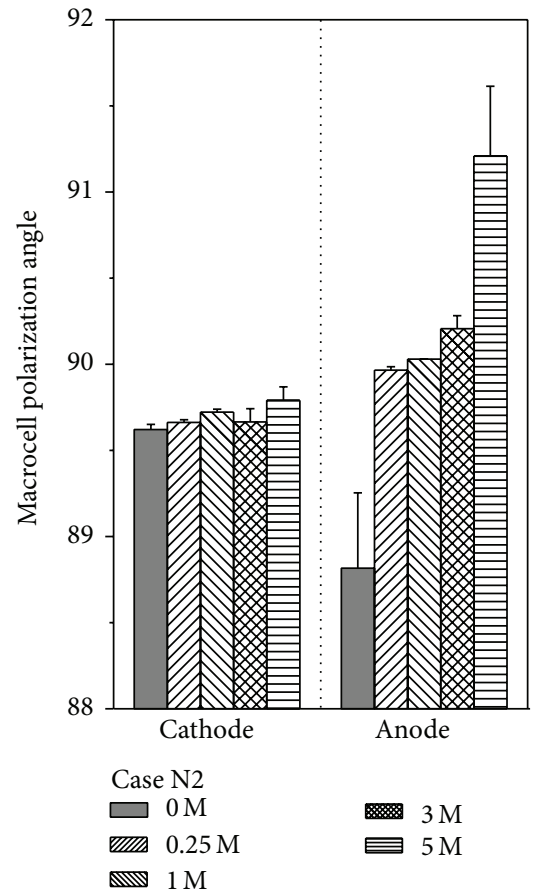

(b)

FIGURE 10: Effect of nitrite concentrations on the macrocell polarization angles of cathode and anode. (a) Case N1, (b) Case N2.

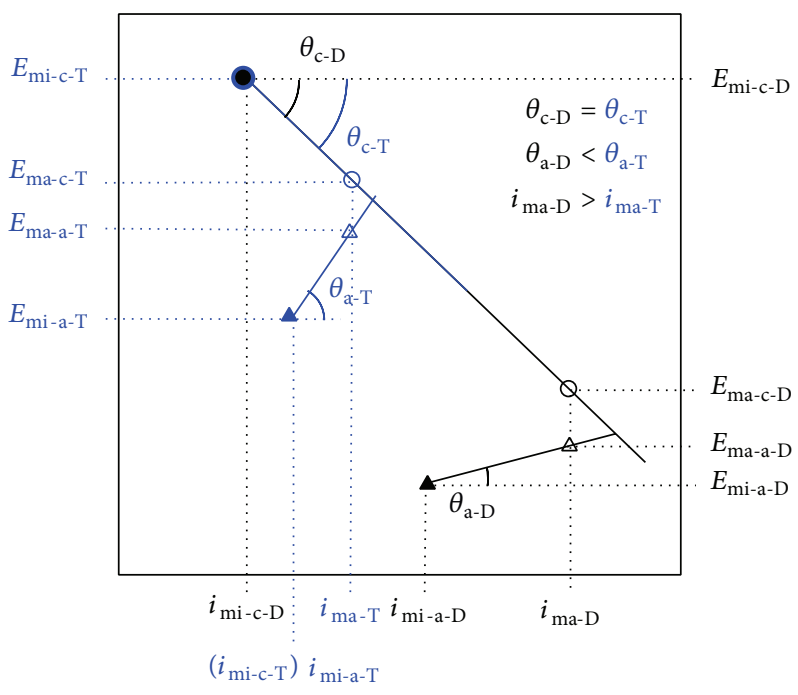

Macrocell polarization of cathode in Cycle D

$\triangle \triangle$ Macrocell polarization of anode in Cycle D

- Macrocell polarization of cathode in Cycle $\mathrm{T}$

$\triangle \triangle$ Macrocell polarization of anode in Cycle $\mathrm{T}$

Cycle D: cathode: no $\mathrm{Cl}^{-}$and no $\mathrm{NO}_{2}{ }^{-}$, anode: with high $\mathrm{Cl}^{-}$and no $\mathrm{NO}_{2}{ }^{-}$

Cycle T: cathode: no $\mathrm{Cl}^{-}$and no $\mathrm{NO}_{2}{ }^{-}$, anode: with high $\mathrm{Cl}^{-}$and with high $\mathrm{NO}_{2}{ }^{-}$

FIGURE 11: Mechanism of macrocell corrosion affected by nitrite ions. 
anode and cathode. It resulted in the decrease of macrocell polarization ratio of cathode and the increase of macrocell polarization ratio of anode.

The gradual increase of nitrite concentration on the surface of anode could lead to the remarkable increase of macrocell polarization slope of anode and had little influence on the macrocell polarization slope of cathode. This means nitrite ions could enhance the macrocell polarization resistance of anode and thus provide effective protection against chloride-induced steel corrosion.

\section{Conflict of Interests}

The authors declare that there is no conflict of interests regarding the publication of this paper.

\section{References}

[1] S. Muralidharan, V. Saraswathy, K. Thangavel, and S. Srinivasan, "Competitive role of inhibitive and aggressive ions in the corrosion of steel in concrete," Journal of Applied Electrochemistry, vol. 30, no. 11, pp. 1255-1259, 2000.

[2] Y. H. Huang and T. C. Zhang, "Nitrite reduction and formation of corrosion coatings in zerovalent iron systems," Chemosphere, vol. 64, no. 6, pp. 937-943, 2006.

[3] M. B. Valcarce and M. Vázquez, "Carbon steel passivity examined in solutions with a low degree of carbonation: the effect of chloride and nitrite ions," Materials Chemistry and Physics, vol. 115, no. 1, pp. 313-321, 2009.

[4] M. Reffass, R. Sabot, M. Jeannin, C. Berziou, and P. Refait, "Effects of $\mathrm{NO}_{2}^{-}$ions on localised corrosion of steel in $\mathrm{NaHCO}_{3}$ $+\mathrm{NaCl}$ electrolytes," Electrochimica Acta, vol. 52, no. 27, pp. 7599-7606, 2007.

[5] L. Dhouibi, P. Refait, E. Triki, and J. M. R. Génin, "Interactions between nitrites and $\mathrm{Fe}(\mathrm{II})$-containing phases during corrosion of iron in concrete-simulating electrolytes," Journal of Materials Science, vol. 41, no. 15, pp. 4928-4936, 2006.

[6] O. Girèienë, M. Samulevièienë, A. Sudavièius, R. Ramanauskas, and L. Lapuchin, "Efficiency of steel corrosion inhibitor calcium nitrite in alkaline solutions and concrete structures," Chemija, vol. 16, no. 3-4, pp. 1-6, 2005.

[7] K. K. Sideris and A. E. Savva, "Durability of mixtures containing calcium nitrite based corrosion inhibitor," Cement and Concrete Composites, vol. 27, no. 2, pp. 277-287, 2005.

[8] K. Y. Ann and N. R. Buenfeld, "The effect of calcium nitrite on the chloride-induced corrosion of steel in concrete," Magazine of Concrete Research, vol. 59, no. 9, pp. 689-697, 2007.

[9] M. Balonis and F. P. Glasser, "Calcium nitrite corrosion inhibitor in portland cement: influence of nitrite on chloride binding and mineralogy," Journal of the American Ceramic Society, vol. 94, no. 7, pp. 2230-2241, 2011.

[10] M. B. Valcarce, C. López, and M. Vázquez, "The role of chloride, nitrite and carbonate ions on carbon steel passivity studied in simulating concrete pore solutions," Journal of the Electrochemical Society, vol. 159, no. 5, pp. C244-C251, 2012.

[11] C. Alonso and C. Andrade, "Effect of nitrite as a corrosion inhibitor in contaminated and chloride-free carbonated mortars," ACI Materials Journal, vol. 87, no. 2, pp. 130-137, 1990.

[12] V. T. Ngala, C. L. Page, and M. M. Page, "Corrosion inhibitor systems for remedial treatment of reinforced concrete. Part 1 : calcium nitrite," Corrosion Science, vol. 44, no. 9, pp. 2073-2087, 2002.

[13] P. Montes, T. W. Bremner, and D. H. Lister, "Influence of calcium nitrite inhibitor and crack width on corrosion of steel in high performance concrete subjected to a simulated marine environment," Cement and Concrete Composites, vol. 26, no. 3, pp. 243-253, 2004.

[14] I. L. Kondratova, P. Montes, and T. W. Bremner, "Natural marine exposure results for reinforced concrete slabs with corrosion inhibitors," Cement and Concrete Composites, vol. 25, no. 4-5, pp. 483-490, 2003.

[15] A. Królikowski and J. Kuziak, "Impedance study on calcium nitrite as a penetrating corrosion inhibitor for steel in concrete," Electrochimica Acta, vol. 56, no. 23, pp. 7845-7853, 2011.

[16] M. B. Valcarce and M. Vázquez, "Carbon steel passivity examined in alkaline solutions: the effect of chloride and nitrite ions," Electrochimica Acta, vol. 53, no. 15, pp. 5007-5015, 2008.

[17] Z. Cao, M. Hibino, and H. Goda, "Effect of nitrite ions on steel corrosion induced by chloride or sulfate Ions," International Journal of Corrosion, vol. 2013, Article ID 853730, 16 pages, 2013.

[18] P. Garcés, P. Saura, E. Zornoza, and C. Andrade, "Influence of $\mathrm{pH}$ on the nitrite corrosion inhibition of reinforcing steel in simulated concrete pore solution," Corrosion Science, vol. 53, no. 12, pp. 3991-4000, 2011.

[19] P. Garcés, P. Saura, A. Méndez, E. Zornoza, and C. Andrade, "Effect of nitrite in corrosion of reinforcing steel in neutral and acid solutions simulating the electrolytic environments of micropores of concrete in the propagation period," Corrosion Science, vol. 50, no. 2, pp. 498-509, 2008.

[20] L. Mammoliti, C. M. Hansson, and B. B. Hope, "Corrosion inhibitors in concrete Part II: effect on chloride threshold values for corrosion of steel in synthetic pore solutions," Cement and Concrete Research, vol. 29, no. 10, pp. 1583-1589, 1999.

[21] Z. L. Cao, M. Hibino, and H. Goda, "Effect of steel surface conditions on the macro-cell polarization behavior of reinforcing steel," Applied Mechanics and Materials, vol. 584-586, pp. 17711779, 2014.

[22] Z. Cao, M. Hibino, and H. Goda, "Effect of water-cement ratio on the macrocell polarization behavior of reinforcing steel," Journal of Engineering, vol. 2014, Article ID 925410, 11 pages, 2014.

[23] C. M. Hansson, A. Poursaee, and A. Laurent, "Macrocell and microcell corrosion of steel in ordinary Portland cement and high performance concretes," Cement and Concrete Research, vol. 36, no. 11, pp. 2098-2102, 2006.

[24] A. Poursaee, A. Laurent, and C. M. Hansson, "Corrosion of steel bars in OPC mortar exposed to $\mathrm{NaCl}, \mathrm{MgCl} 2$ and $\mathrm{CaCl} 2$ : macro- and micro-cell corrosion perspective," Cement and Concrete Research, vol. 40, no. 3, pp. 426-430, 2010.

[25] T. Maruya, H. Takeda, K. Horiguchi, S. Koyama, and K.-L. Hsu, "Simulation of steel corrosion in concrete based on the model of macro-cell corrosion circuit," Journal of Advanced Concrete Technology, vol. 5, no. 3, pp. 343-362, 2007.

[26] C. Andrade, I. R. Maribona, S. Feliu, J. A. González, and S. Feliu Jr., "The effect of macrocells between active and passive areas of steel reinforcements," Corrosion Science, vol. 33, no. 2, pp. 237249, 1992.

[27] C. M. Hansson, L. Mammoliti, and B. B. Hope, "Corrosion inhibitors in concrete-part I: the principles," Cement and Concrete Research, vol. 28, no. 12, pp. 1775-1781, 1998. 
[28] R. R. Hussain, T. Ishida, and M. Wasim, "Oxygen transport and corrosion of steel in concrete under varying concrete cover, w/c, and moisture," ACI Materials Journal, vol. 109, no. 1, pp. 310, 2012.

[29] W. López and J. A. González, "Influence of the degree of pore saturation on the resistivity of concrete and the corrosion rate of steel reinforcement," Cement and Concrete Research, vol. 23, no. 2, pp. 368-376, 1993.

[30] B. Elsener and U. Angst, "Mechanism of electrochemical chloride removal," Corrosion Science, vol. 49, no. 12, pp. 4504-4522, 2007.

[31] U. Angst, B. Elsener, C. K. Larsen, and Ø. Vennesland, "Critical chloride content in reinforced concrete-a review," Cement and Concrete Research, vol. 39, no. 12, pp. 1122-1138, 2009.

[32] J. Tritthart and P. F. G. Banfill, "Nitrite binding in cement," Cement and Concrete Research, vol. 31, no. 7, pp. 1093-1100, 2001. 

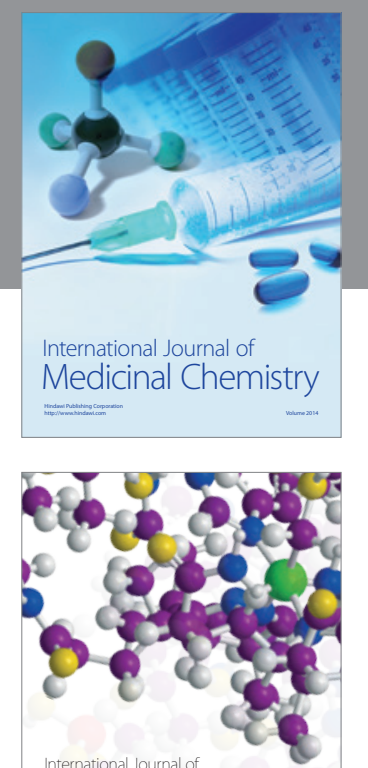

\section{Carbohydrate} Chemistry

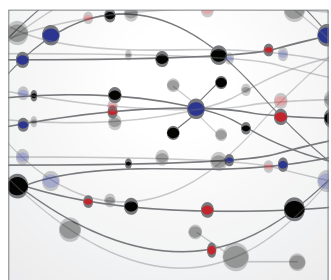

The Scientific World Journal
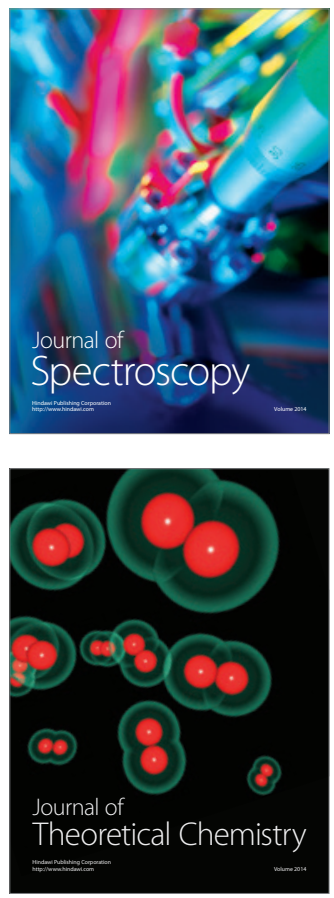
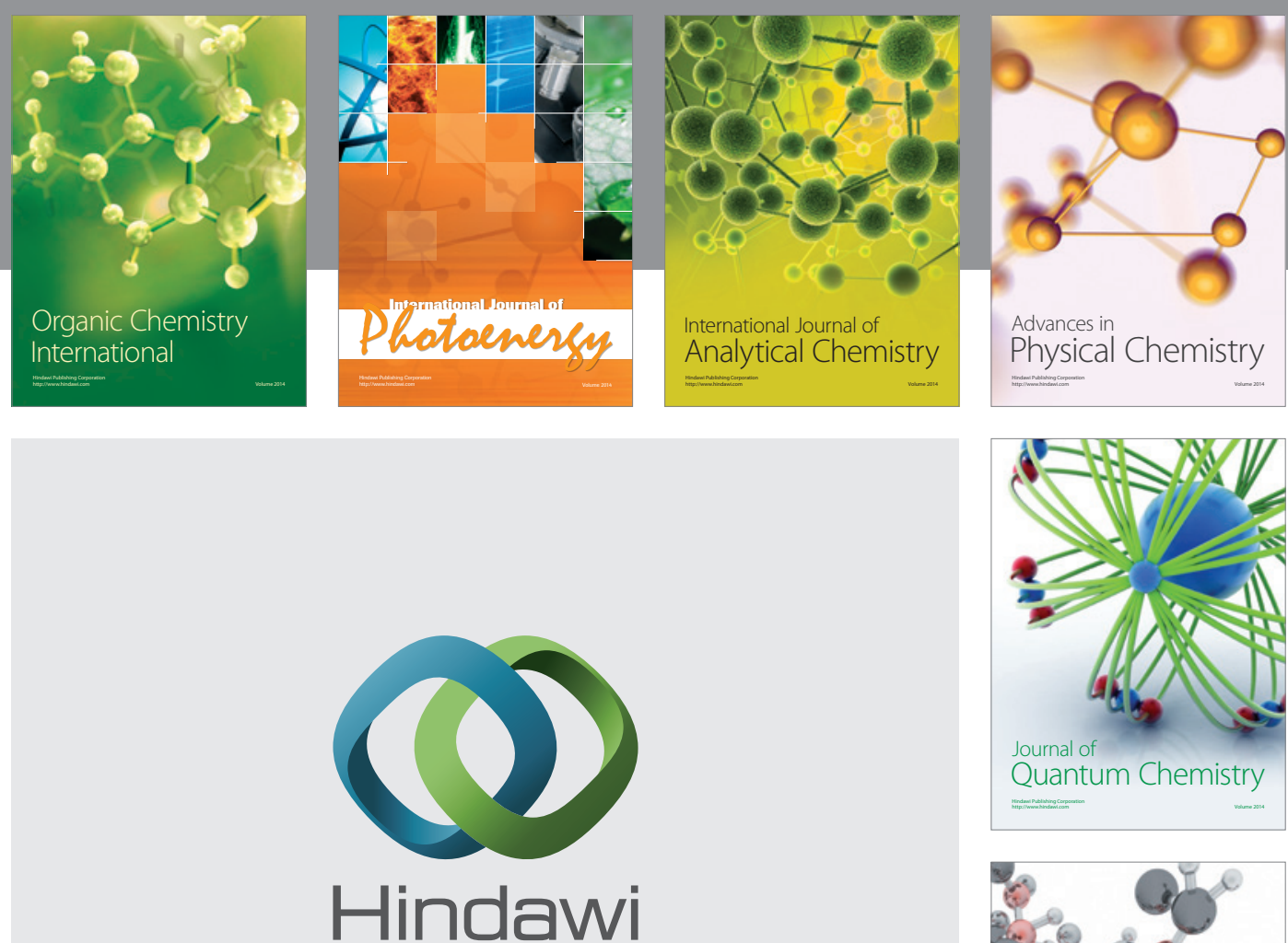

Submit your manuscripts at

http://www.hindawi.com

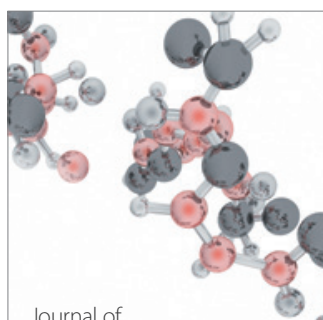

Analytical Methods

in Chemistry

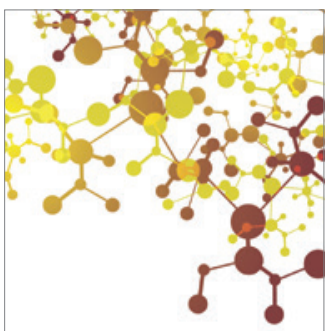

Journal of

Applied Chemistry

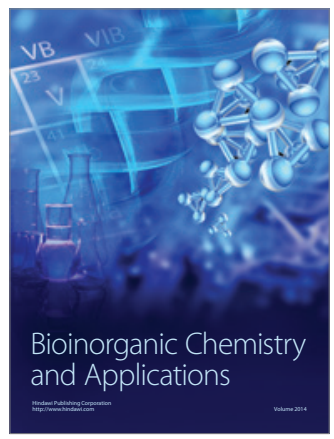

Inorganic Chemistry
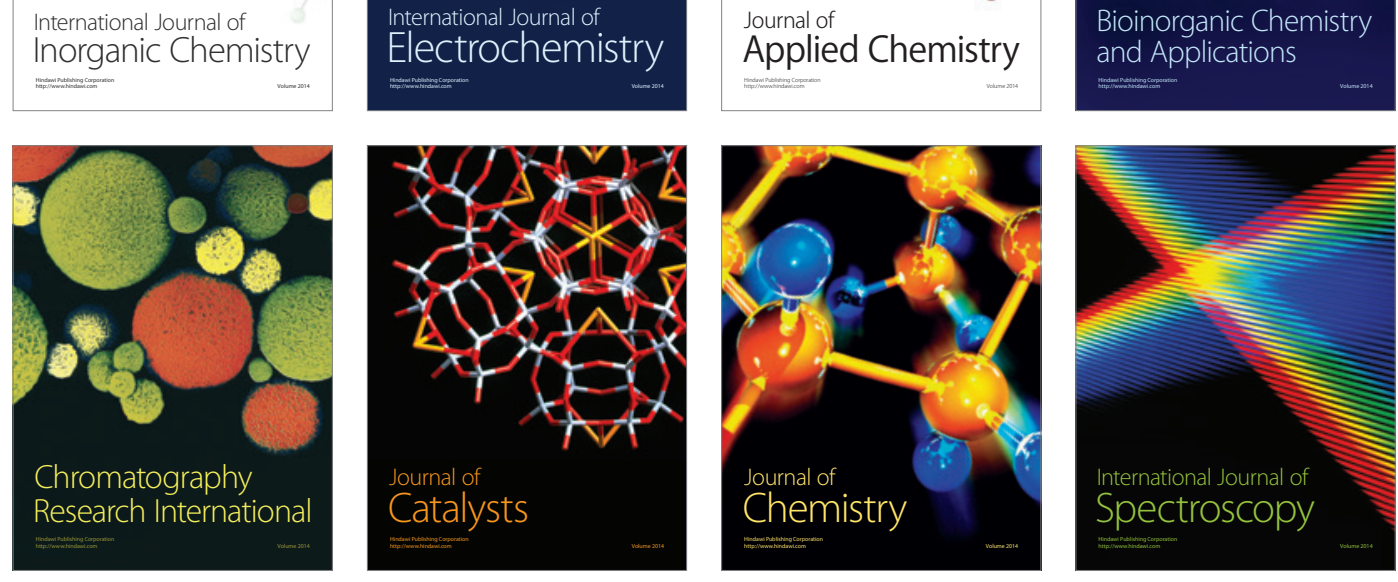